\title{
CLASSIC-PERIOD RITUAL CERAMICS FROM THE COAST OF CHIAPAS, MEXICO
}

\author{
Barbara Voorhies and Margaret Arvey ${ }^{\mathrm{b}}$ \\ a'Department of Anthropology, University of California-Santa Barbara, Santa Barbara, California 93106-3210 \\ b1410 East Mountain Drive, Santa Barbara, California 93108-1217
}

\begin{abstract}
In 1947 Philip Drucker excavated an unusually dense concentration of artifacts from the plaza of a small Late Classic site on the inner coastal plain of Chiapas, Mexico that he proposed was a possible end-of-cycle ceremonial dump. Although the deposit contained both utilitarian and ritual items, only some of the latter have survived for present day investigation. Here we describe Drucker's excavations and the surviving ritual items, neither of which had ever been published in detail. We also examine archaeological expectations for end-ofcycle dumps based upon ethnohistoric descriptions of this Mesoamerican ritual practice and we explore the iconography of effigy censers, which constitute an important set of the items that Drucker collected. We conclude that this singular deposit most likely represents the material remains an end-of-cycle ritual as Drucker had originally proposed.
\end{abstract}

\section{INTRODUCTION}

We report an assemblage of ritual ceramic objects that were recovered by archaeologist Philip Drucker in 1947 from a small Classicperiod site on the Chiapas coastal plain of southern Mexico (Drucker 1948). The objects were massed together in a single deposit that Drucker excavated in the site's plaza. The depositional circumstances and the nature of the objects themselves led Drucker to surmise they were "... ceremonial goods dumped, perhaps at the end of some calendric ritual period" (Drucker 1948:165). In this article we describe the objects and make the case that Drucker's original interpretation of this deposit is likely correct.

In the first section we discuss the archaeological site, Las Delicias, in which Drucker found the ceramic assemblage, and present information about this discovery that we argue makes it a good candidate for an end-of-cycle ceremonial dump. In the second section we describe some of the objects that Drucker recovered from the deposit. Finally, we speculate about what may have been the occasion for burying this material.

The significance of this material is twofold. First, it consists of an intact assemblage of ritual items associated with the universalistic pan-Mesoamerican religion prevalent during the Classic period. Second, these items, recovered from a small, undistinguished site located near the southernmost limit of the Mesoamerican realm, illustrate the extent and degree of ideological penetration during the Classic period.

\section{DRUCKER'S INVESTIGATIONS AT LAS DELICIAS}

In 1947 Philip Drucker conducted an archaeological survey of the coast of Chiapas, Mexico. One of the sites that he investigated was Las Delicias, a very small platform mound site (Figure 1) that

E-mail correspondence to: voorhies@anth.ucsb.edu we now know is not particularly distinguished from other similar sites on the flat-lying alluvial plain of the Chiapas coast (Voorhies 1989; Voorhies et al. 2011). The site is located $8-10 \mathrm{~km}$ south of the former Soconusco rail station (Drucker 1948:165) and within the Soconusco Ejido, once part of the Doña Maria finca (Drucker 1947:63). At the time of Drucker's study the ejido parcel belonged to the Montes family.

According to Drucker's field notes and sketch map (Figure 2) there were three principal platform mounds at the site, along with several smaller ones. These three principal mounds circumscribed an open space or "plaza." The platform mound on the east side of the plaza was pyramidal. Its footprint measured $24 \times 20 \mathrm{~m}$ at the base and Drucker estimated its original height was perhaps $2.5 \mathrm{~m}$ (Drucker 1948:165). At the time of his visit it had been leveled slightly by the property owner who had built his house on the summit (Drucker 1947:64) (Figure 3). The owner told Drucker that he encountered abundant river cobbles during the construction of his house. We take this to mean that the mound had cobble facing, a common construction technique on the Chiapas coast at archaeological sites with platform mounds that are located on the inner coast where cobbles are abundant in river beds.

Drucker describes a second platform mound about $15 \mathrm{~m}$ west of the first one as a "low long barrow" measuring approximately $30 \mathrm{~m}$ long, $15 \mathrm{~m}$ wide and between 1.00 and $1.50 \mathrm{~m}$ high. He describes a third mound that is about $40 \mathrm{~m}$ northwest of the first mound. Drucker's field sketch (Figure 2) shows that this platform is parallel to the "long barrow," and the dimensions are similar to it except for the height, which is recorded as $1.00 \mathrm{~m}$. Although our descriptions of the second and third platforms may sound to the reader like the paired platforms of a ball court, Drucker's sketch map shows clearly that they actually are two opposing sides of a plaza. Drucker also reports in his field notes that potsherds were abundant on the ground surface in the vicinity of these principal mounds. Drucker (1947) also mentions two other small platform mounds 


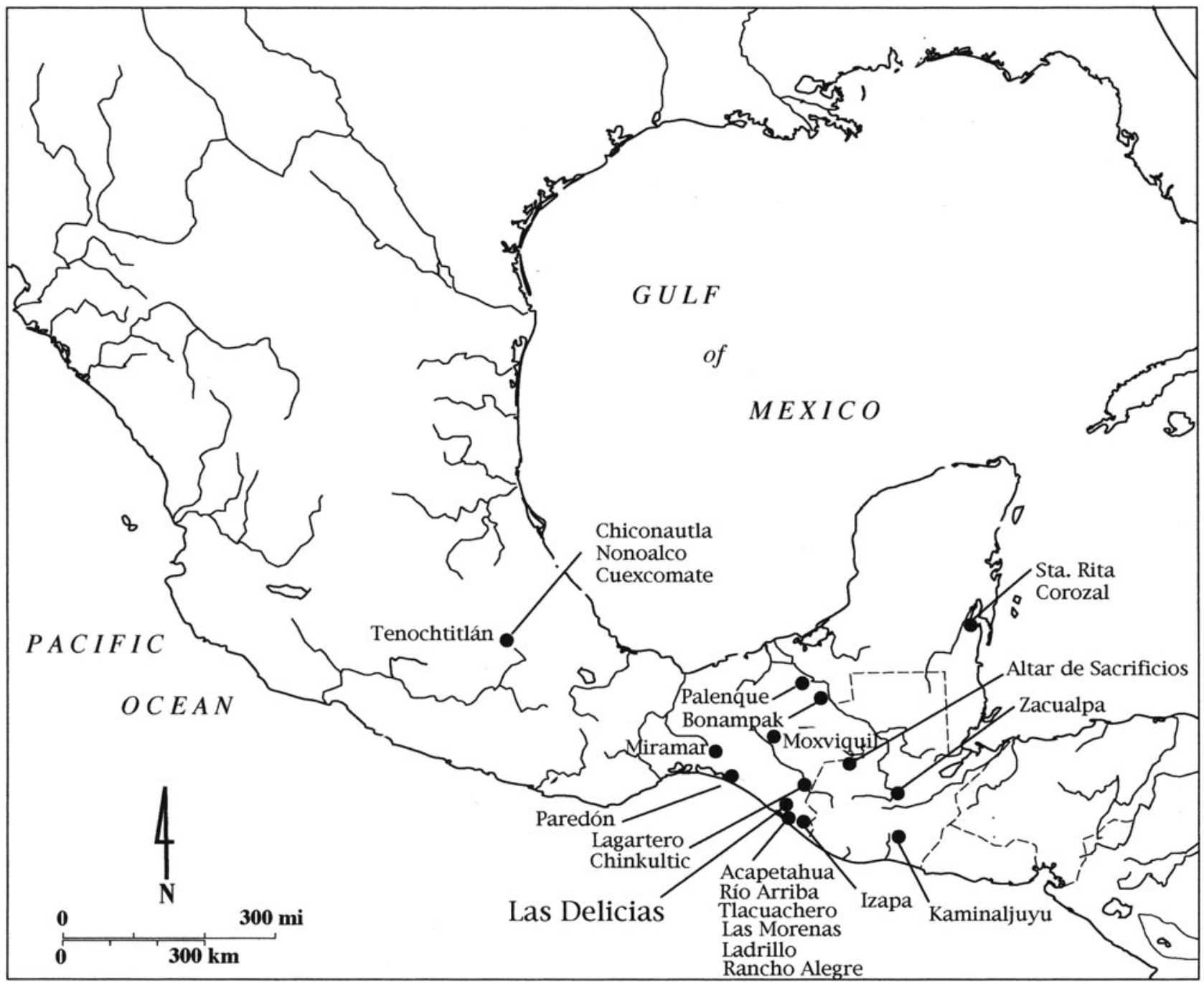

Figure 1. Map of Mesoamerica with archaeological sites mentioned in text. (Map by Aura de Anda).

that are located 130-150 m east-southeast of the principal mound group. On his sketch map these are drawn as circular in plan view and described as $1.0 \mathrm{~m}$ and $1.5 \mathrm{~m}$ high. Another small mound, drawn faintly with a circular plan, appears on his sketch map northeast of Mound 1 but he does not mention it in his field notes.

Drucker excavated two locations at the site. The first (labeled by Drucker as Las Del-1) was placed "on top of the smaller mound" (Drucker 1947:64). Apparently this excavation was in the eastern pyramidal mound. Drucker recovered some ceramic material in the upper 12 in $(30 \mathrm{~cm})$, below which was "light yellow clay fill with no sherds" (Drucker 1947:64). Thus it seems that the mound consisted of nearly sterile construction fill, rather than debris from earlier occupational phases. This could mean that Las Delicias is a single component site.

Las Del-2 is the excavation of principal interest to us. It was situated within the plaza adjacent to and parallel with the long mound on the north side of the plaza. This is apparently the black rectangle on Drucker's sketch map (Figure 2). The horizontal dimensions of the excavation are recorded as $6^{\prime} \times 20^{\prime}(1.82 \times 6.06 \mathrm{~m})$ (Drucker 1947:65). At 10" (25 cm) Drucker encountered a deposit of large potsherds from ornate vessels that in his field notes he refers to as a "cache or offering" of large incense burners (Drucker 1947:65;
Figure 4). He reports that there were traces of "ashes" among the potsherds but no bone (Drucker 1947:65). The smashed pottery objects extended to a depth of at least $28^{\prime \prime}(70 \mathrm{~cm})$. Below $28^{\prime \prime}$ Drucker encountered a "clayey soil" containing a few potsherds and charcoal in the "upper few inches" but which became sterile at $34^{\prime \prime}(85 \mathrm{~cm})$. Drucker also reports that sherds of domestic pottery were found mixed with the large incense burners (Drucker 1947:65). This observation is important for our interpretation of this deposit as a ceremonial dump, as we explain below.

Drucker brought eight crates of the material from Las Delicias back to the United States where they languished for many years in storage at the National Museum of Natural History, Smithsonian Institution, along with all of the other materials he collected during the same field season. In 1980 Clifford Evans, Curator of Anthropology, sent the entire collection to Voorhies for study purposes. By that time the material had suffered greatly from neglect and the ravages of time. During the summer of that year Linda Pfeiffer, then a graduate student at the University of California, Santa Barbara, processed the Drucker materials. In the case of the collection of pottery objects from Las Delicias, Pfeiffer unpacked the crates, many of which had never been opened, salvaged surviving information about provenience from 


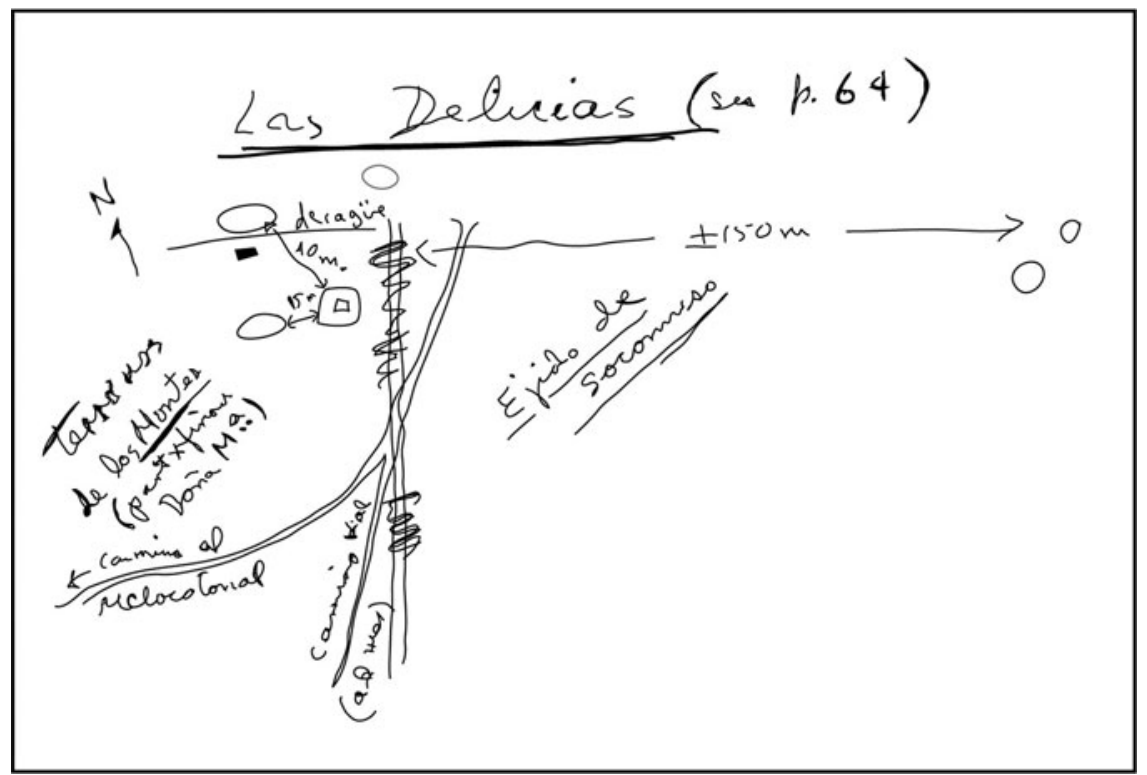

Figure 2. Drucker's sketch map of the site of Las Delicias. The small black rectangle is Las Del-2, the location where the large incense braziers and other items were found. (Drawn by Aura de Anda from Drucker 1947:63).

deteriorated labels, and washed the sherds. Pfeiffer dated the objects to the Late Classic period based on comparisons with other ceramic chronologies in Chiapas that were then available.

Although all the objects were broken, it was possible to partially refit some of them. Drucker reports in his field notes that the deposit extended in all directions from his excavation, which probably explains why only partial refitting was accomplished. Student volunteers first at the University of California, Santa Barbara (UCSB) and later at the University of Colorado, Boulder (CU-Boulder), refitted these objects. Jack Scott, a professional illustrator, then made accurate drawings of several refitted objects. In 1998 Voorhies donated the collection to the Museum of Natural History at the University of Colorado, Boulder but it was subsequently moved for curation to the Smithsonian Institution.

\section{A POSSIBLE END-OF-CYCLE DUMP?}

Why do we think this material came from a ceremonial dump? We make this argument based in part upon the archaeological context of

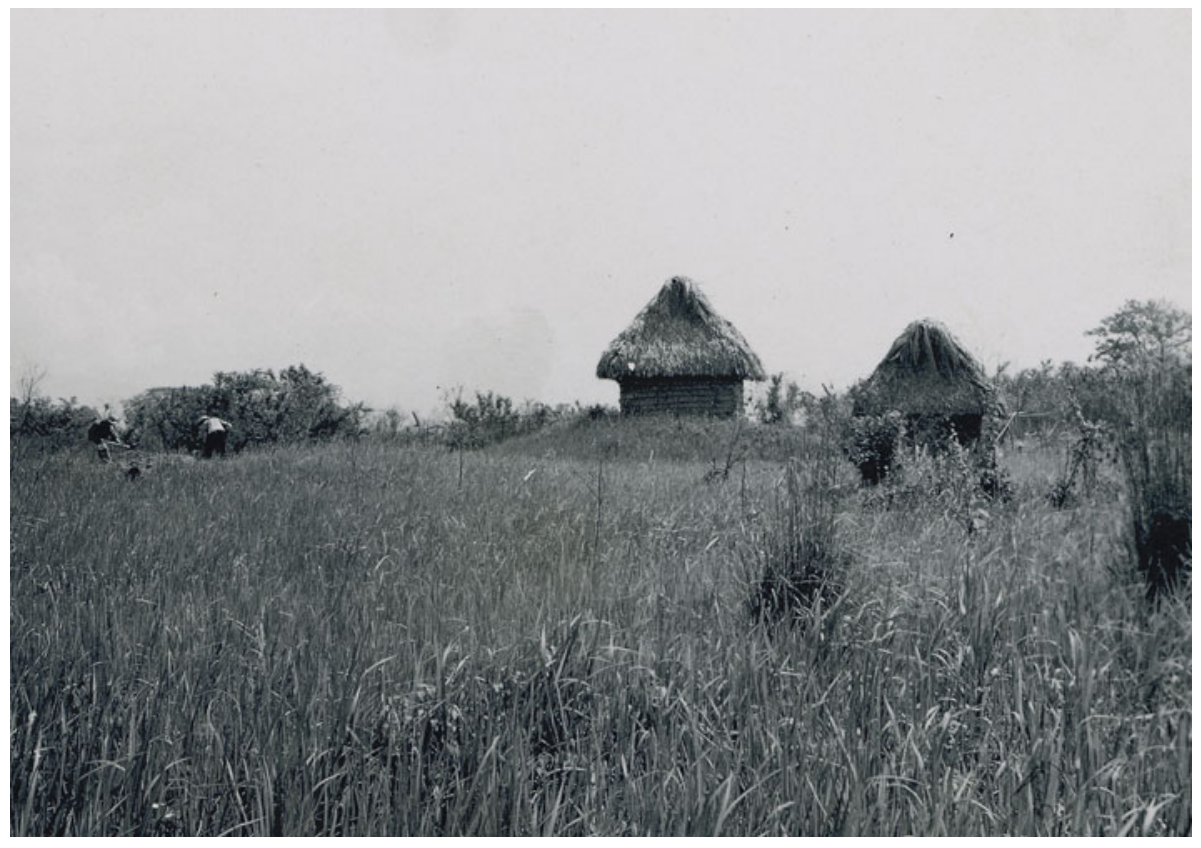

Figure 3. Drucker's photograph of Las Delicias. The building on the left is positioned at the summit of Mound 1. To its left two men are excavating at Las Del-2. National Anthropological Archives, Smithsonian Institution (65703). 


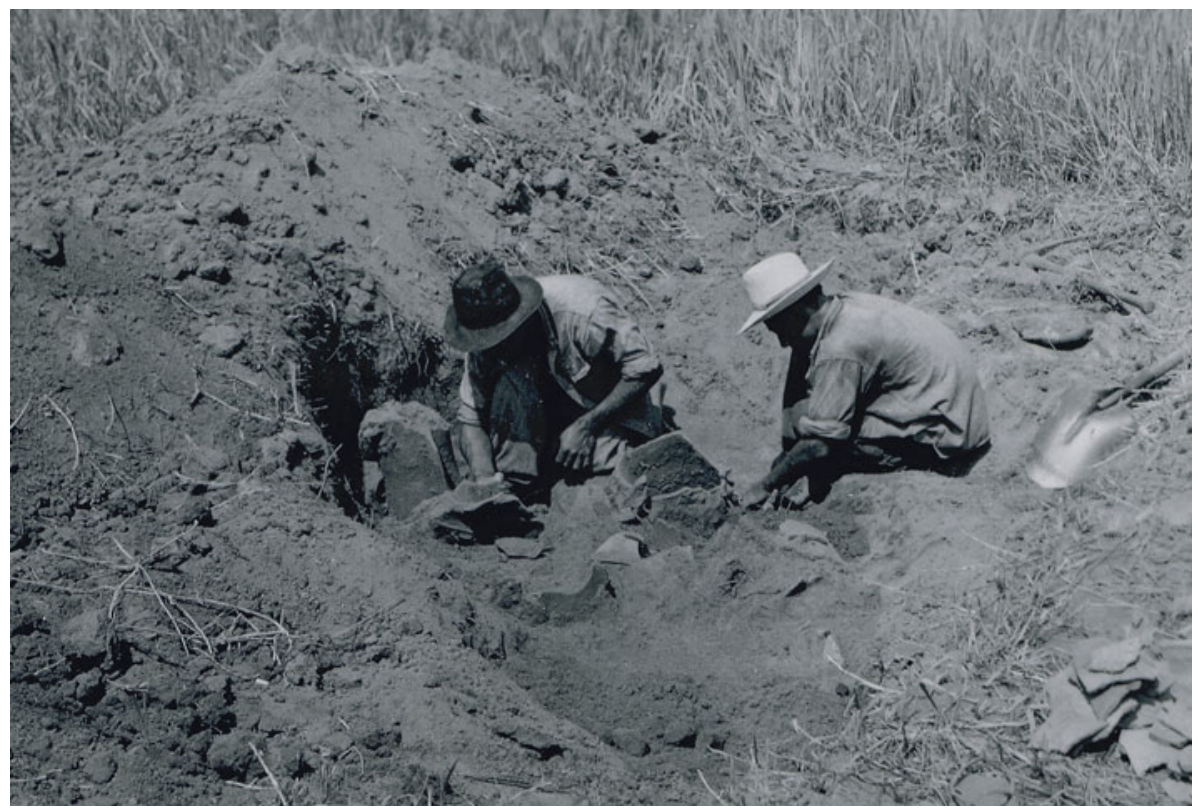

Figure 4. Drucker's photograph of excavations at Las Del-2 showing the recovery of a "cache or offering" of large incensarios. National Anthropological Archives, Smithsonian Institution (65702).

the assemblage, as advocated by Ball and Taschek (2007), as well as upon strong ethnohistoric analogies.

Among ancient Mesoamerican societies for which we have protohistoric data, certain end-of-cycle events were celebrated by discarding old objects and replacing them with new ones. One such Aztec event, the New Fire Ceremony, took place every 52 years (Sahagún 1953:bk. 7, 25ff). At that time the fires burning in temples and houses were extinguished and objects were discarded. Sahagún's illustrator shows a man discarding a broken tripod vessel, dishes, jars, hearthstones, and a basketry box, as well as an anthropomorphic cult image (Figure 5).

Like the Aztecs, the sixteenth-century Yucatec Maya practiced renewal ceremonies, which in this case are described by Bishop Landa. The following passage discusses annual New Year ceremonies; Landa does not mention festivals associated with 52-year cycle endings among the Yucatec Maya (Tozzer 1966[1941]:151, n. 750).

"The first day of Pop, which is the first month of the Indians, was their new year and was a very solemn festival among them; as it was universal and all took part in it and so the whole town jointly made the feast to all the idols. To celebrate it with more solemnity, they renewed on this day all the objects that they made use of, such as plates, vessels, stools, mats and the old clothes and stuffs with which they wrapped up their idols. They swept out the houses and the old utensils they threw out on the waste heap outside the town; and no one, even if he were in need, touched it" (Tozzer 1966[1941]:151).

Based on the protohistoric sources, a ritual dump should exhibit certain characteristics, which we outline below, and that differ from other types of archaeological deposits. The listed characteristics of ritual dumps are similar to those proposed by Elson and Smith (2001) for the Aztec New Fire Ceremony, but we have broadened them in order to include information about Mesoamerican renewal ceremonies in general. The archaeological expectations of these ceremonial dumps are the following:

- There should be a high proportion of ritual items compared to utilitarian objects.
- The sizes of individual fragments should be relatively large.

- The density of the artifacts per volume of excavated material should be exceptionally high.

- The feature should be unstratified.

- The artifacts within the feature should all date to the same time period.

- Many artifacts should be refittable and the refitting should cross horizontal and vertical distances within the feature.

Elson and Smith (2001) contrast these expectations for a ritual dump with those of a midden that might be present at the same site as the suspected ritual dump deposit. Other scholars (e.g., Rosenswig 2009; Schiffer 1983, 1987; Stark and Ohnersorgen 2001) have elaborated on closely related topics of formation processes and expected patterning of artifacts and deposit morphology for various types of residential waste. Basically, the archaeological expectations for discarded residential trash are: a high proportion of utilitarian items compared with ritual items, artifact fragments that are relatively small, a relatively low density of artifacts (due to a significant amount of sediment), many broken and damaged artifacts that cannot be refitted, and possibly, but not necessarily, some stratification of the feature and chronological differentiation of the artifacts.

The deposit at Las Del-2 conforms well to the expectations of a ritual dump. From Drucker's $(1947,1948)$ descriptions, the deposit had an exceptionally high density of material, ceramic fragments are large, the feature was apparently unstratified, and refitting cuts across the feature both horizontally and vertically. What we cannot assess, however, is how this feature compares to residential middens at the same site as called for by Elson and Smith (2001), since Drucker did not excavate any residential middens or trash pits at Las Delicias. Nevertheless, the deposit described by Drucker does not conform well to the expectations for residential trash.

We now turn to the ritual objects that Drucker found in this deposit at Las Delicias. Drucker notes that in addition to the ritual items there were utilitarian objects in the excavated feature, but he did not document or collect them. The ritual assemblage contains 


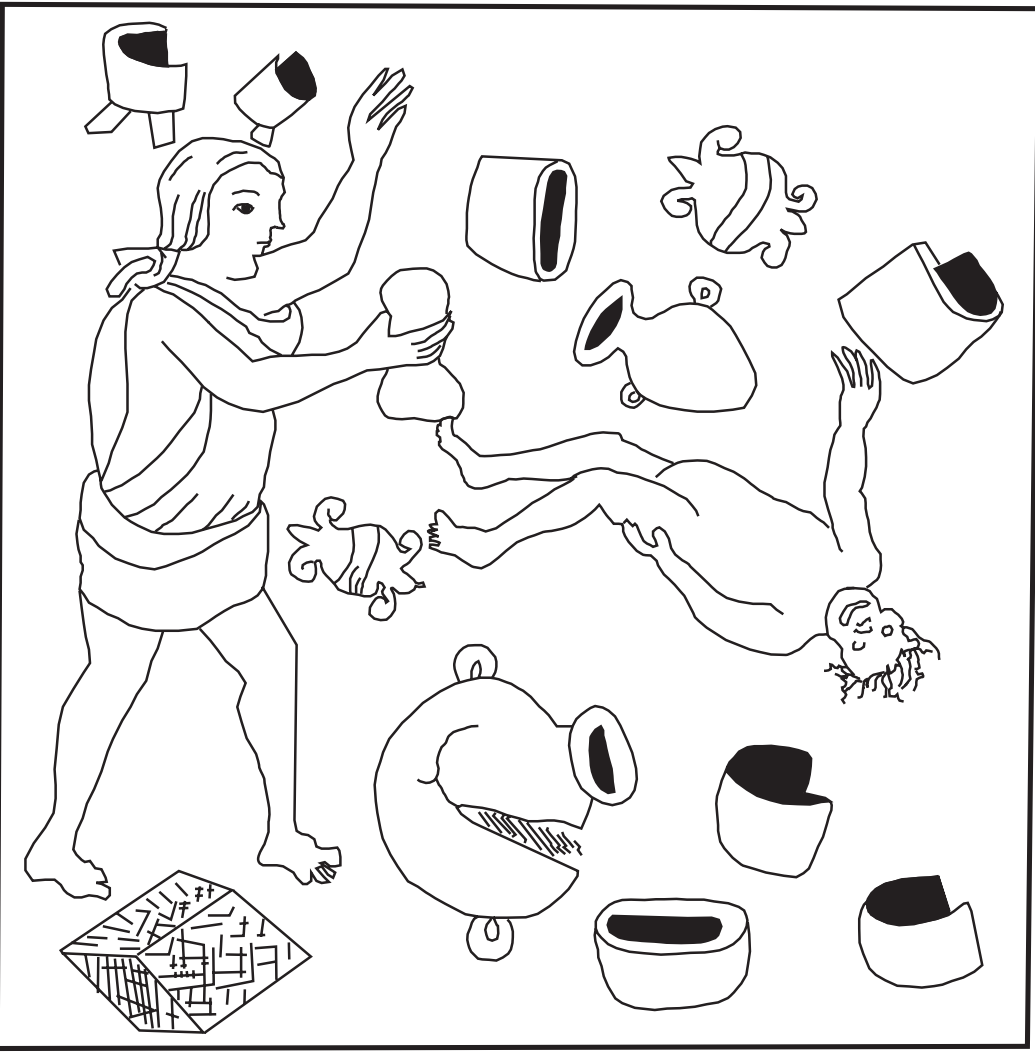

Figure 5. An illustration from Sahagún showing an Aztec man discarding used household items at the end of a 52-year calendric cycle (Sahagún 1953:ill. 19). The items being discarded include a broken tripod vessel, dishes, jars, hearthstones, and a basketry box or stool, as well as an anthropomorphic statue. (Drawn by Dan Van Dorn).

five different classes of items: ladle censers, spiked braziers, columnar censers or censer stands, naturalistic anthropomorphic statues, and effigy censers.

\section{LADLE CENSERS}

Drucker's field notes (1947:65) and subsequent article (Drucker 1948:165) note that fragments of ladle censers were found among the potsherds in the Las Del-2 excavation. Ladle censers are pottery objects consisting of a shallow bowl with a long cylindrical handle extending horizontally from the bowl's side. Sometimes called frying pan incensarios, they are found frequently in archaeological sites in Mesoamerica (Agrinier 1978; Blake et al. 2005) Their function is well-documented in Colonial accounts, especially those pertaining to both the Aztecs (e.g., Sahagún 1953), and the native pictorials of the Mixtecs (e.g., Nuttall 1975, Seler 1963), among the best well-known indigenous groups of that time period. Because of the abundant documentation, there can be no doubt ladle censers were portable vessels used to burn incense. For example, an excellent illustration provided by Sahagún (Figure 6) shows an Aztec woman heating a smoking ladle censer over a three stone hearth. There are many textual descriptions of how ladle censers were used in ritual contexts, but the following passage from Sahagún is especially instructive:

"And thus was the offering of incense performed. It was with an incense ladle made of clay, with (stones in its hollows making) a rattle. There in the ladle they laid live coals. When they had scooped them up then they filled it with copal incense; with it they came forth before the devil or else in the middle of the courtyard, where the brazier stood. (This) was made of clay."

And when they came to stand before the devil, then they raised the incense ladle in dedication to the four directions. Thus they offered incense. And when they raised it in dedication to the four directions, then they threw (the incense and the coals) into the brazier. Then the copal was smoking." (Sahagún 1981:194).

The excavated assemblage from Las Delicias contained several ladle censers as Drucker makes clear: "We also found a number of frying-pan incensarios; a pair of these had knobs at the proximal ends of the handles, thus representing human femora" (Drucker 1948:165). Drucker's sketch map of the excavation shows two ladle censers, one of which is drawn with the two knobs mentioned in the text. These particular ladle incense burners did not arrive at UCSB with the rest of the collection, so we have not examined them.

Ladle censers are commonly found in Classic-period deposits at many archaeological sites, although usually they occur as broken objects that were discarded along with other trash after they were no longer functional. At Las Delicias, however, the depositional context suggests that the ladle censers were part of an assemblage of ritual items that were intentionally broken and discarded together. We know of two instances at archaeological sites in Chiapas where ladle censers occur in similar contexts. 


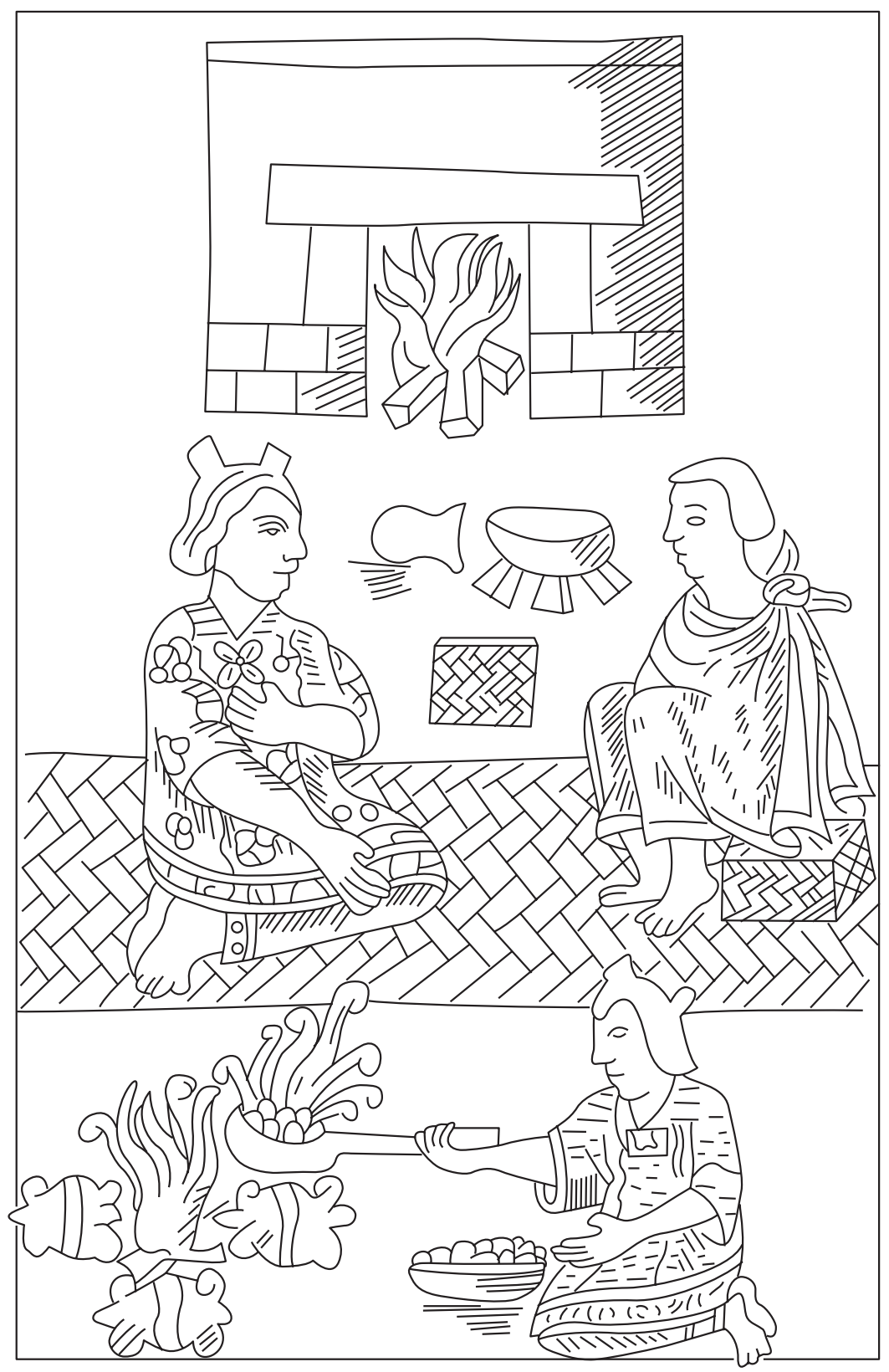

Figure 6. Illustration from Sahagún showing an Aztec couple seated on a woven mat in front of their house where a new fire is burning. A woman burns copal in a long-handled ladle incense burner over a three-stone hearth. A bowl of copal is at her side. (Drawn by Dan Van Dorn from Sahagún 1953:ill. 18).

One site is Miramar, located in the Central Depression of Chiapas (Figure 1). There, Pierre Agrinier (1978) excavated a multiple burial dating to the Middle Classic period that was located in the center of the site's plaza (Agrinier 1978:Figure 37). Intermingled with the mainly articulated skeletons of nineteen individuals, along with three disembodied skulls, Agrinier found 124 ladle censer fragments, as well as fragments of large pottery censers (discussed below). Agrinier contends that because of the positions and arrangement of the skeletons they are likely to have been the victims of a mass execution (Agrinier 1978:3). His report makes clear that the bulk of the ladle and large censer fragments were found on top of the skeletons (Agrinier 1978:23). This suggests to us that ritual paraphernalia were discarded after completion of the sacrifices, which in turn suggests that the items were used to commemorate the event. Agrinier (1978:Figure 36) illustrates a ladle censer handle with two knobs at the proximal end that came from this feature. This handle apparently also represents a human femur like the pair of ladle censers that Drucker describes from Las Delicias. Two other ladle censer handles from the same archaeological context at Miramar have modeled human hands at the proximal ends of the handles (Agrinier 1978:Figure 37). Accordingly, at Miramar ladle censers alluding to human limbs appear to have been used in a ritual resulting in human sacrifice and subsequent burial of the victims in the central plaza. There is no evidence available to indicate the occasion, calendric or otherwise, that motivated this event. 


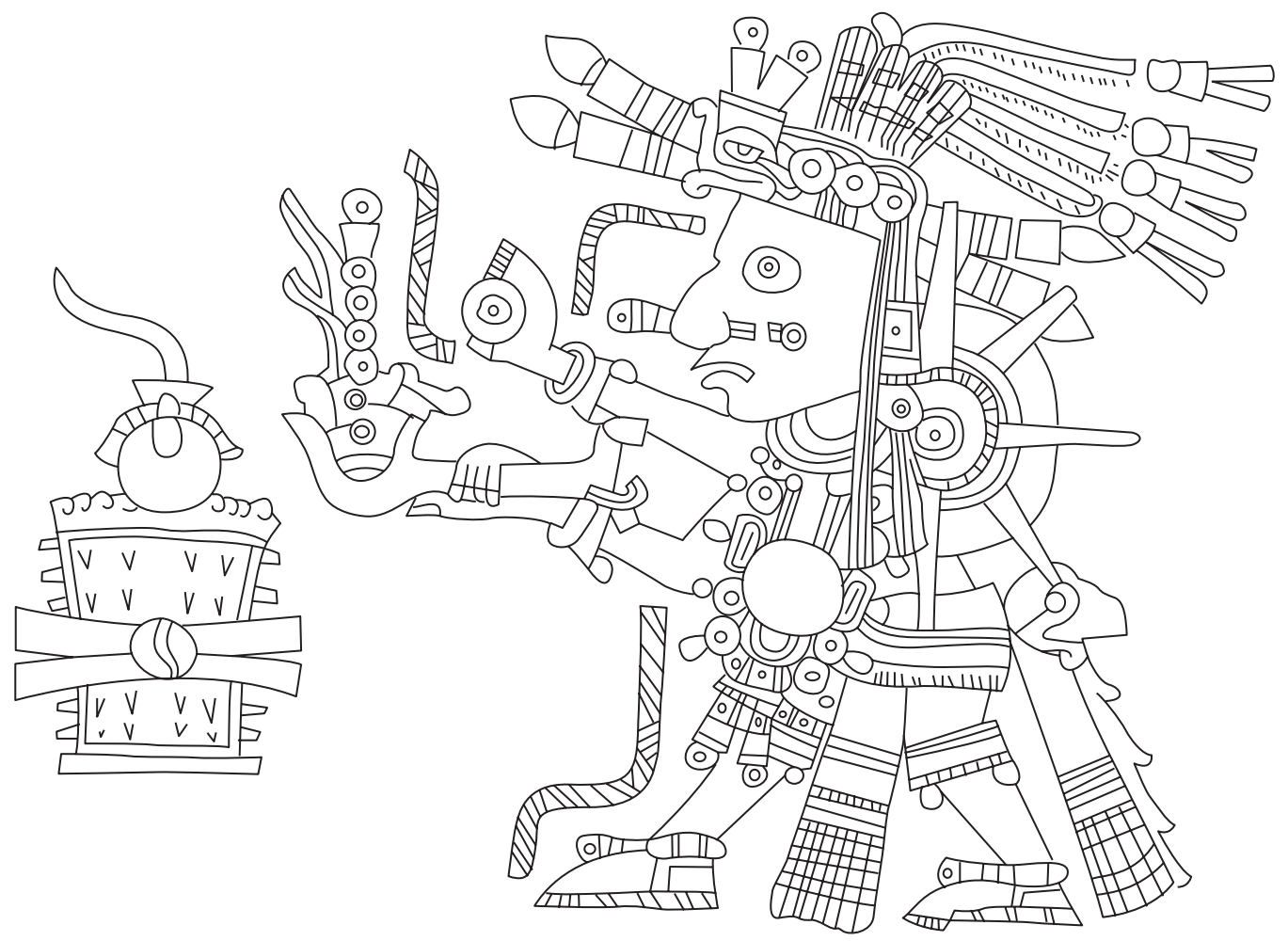

Figure 7. An elaborately costumed individual dressed as Tonatiuh the solar god, holding a smoking ladle incense burner with zoomorphic foot handle. He is approaching a white painted spiked brazier that is positioned in front of a temple that is not shown. From the Codex Borgia (Díaz and Rodgers 1993:Plate 18), a pre-Columbian eastern Nahua manuscript. (Drawn by Dan Van Dorn).

Ladle censers depicting human body parts have been reported from other sites in Chiapas, as well as elsewhere. Of particular significance in this regard is the second site where ladle censers were found in a depositional context suggesting their intentional breakage and ritual deposition. At Lagartero, in the Chiapas highlands (Figure 1), 156 ladle censers with handles terminating in cupped hands (Blake et al. 2005:Table 8.1) were recovered from a ceremonial dump in the central plaza (Blake et al. 2005:447) that contained over 3,000 fragments of ladle censers (Blake et al. 2005:Table 8.1). The excavator, Susanna Ekholm, also found dozens of elaborate burials in the plaza (Clark et al. 2005:12). The feature that is interpreted as a ceremonial dump consisted of a dense concentration of objects, including a wide variety of household and ritual items, many of which could be refitted.

Censer handles that represent arms ending in hands have been found at Zacualpa (Wauchope 1975:225) in the Guatemalan highlands, where the hands appear at the bowl end of the handle. These ladle censers date from the Middle Classic through the Early Postclassic period. One ladle handle, ending in a human foot, was found in probable Late Postclassic period contexts at Acapetahua (Voorhies and Gasco 2004:Figure 6.4) on the Chiapas coast. In the Borgia Codex, a painted book from the eastern Nahua area, a similar ladle censer ending in an animal foot is depicted (Figure 7). Ladle censers whose handles represent human arms occur on a twentieth century object made by the Lacandon Maya (Tozzer 1907:110).

The persistent motifs of human and non-human limbs on portable incense burners, depicted either with flesh or skeletonized, may reference the theme of sacrifice. This idea gains support from the occurrence of such ladle censers along with sacrificed humans at
Miramar. Whether or not this is correct, we know from the archaeological record that such ladle censers were sometimes ritually deposited in the central plazas of sites.

\section{SPIKED BRAZIERS}

Another group of objects from the Las Delicias plaza excavation consists of spiked censer fragments. Incense burners with exterior spikes have long been part of the ritual equipment in Mesoamerica, extending from at least the Middle or Late Preclassic period (Borhegyi 1951a, 1951b; Lowe 1965) to today (Deal 1982). They are found in archaeological deposits and are also depicted in artistic representations during much of this long period (e.g., Figure 7). The form of these censers varies through time and space, as might be expected, but consistently they are associated with religious ritual, generally the burning of incense. There can be no doubt that spiked vessels constitute part of the basic ritual paraphernalia in Mesoamerican religious tradition.

Although we were unable to refit substantial portions of any one of the broken spiked censers from the Las Delicias collection we have a fairly good idea of their former appearance, in part because of a similar reconstructed censer from the nearby site of Acapetahua (Voorhies and Gasco 2004:Figure 2.16). The Acapetahua object was found in Late Classic period deposits associated with a small platform mound (Voorhies and Gasco 2004: Figure 2.14) located within the part of the site that was planned and constructed during the Classic period.

The spiked vessels from Las Delicias and Acapetahua are large cylinders that are narrower in their midsections compared to their rims, giving them a slight hourglass shape. Although we were 


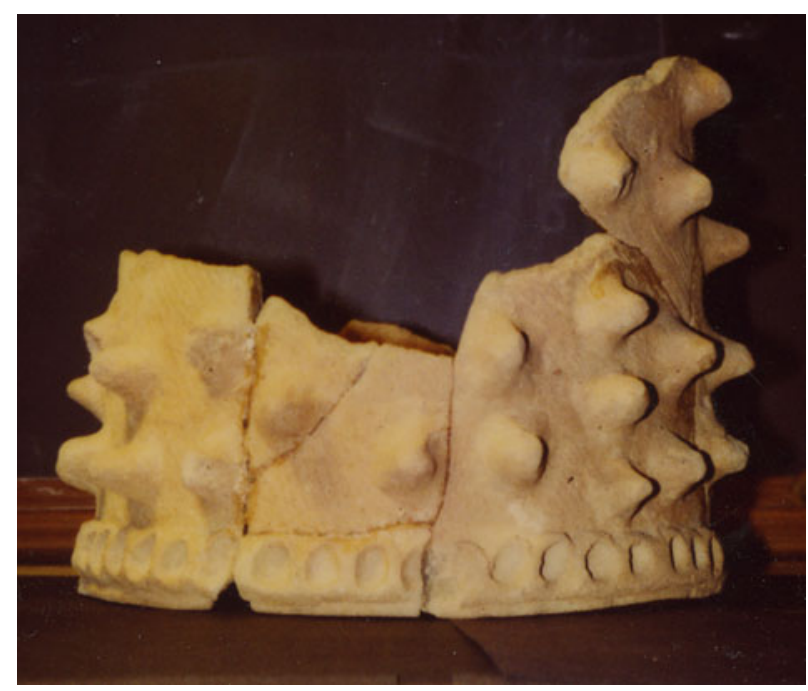

Figure 8. Photograph of a refitted rim from a spiked brazier from Las Delicias. (Photograph by Jack Scott).

unable to determine the original height of the Las Delicias censers, their rim diameters range from 29 to $42 \mathrm{~cm}$. They are modeled out of a low fired, coarse paste, which typically is tan or reddish orange in color. A horizontal platform divides the hollow interior into two chambers. One of the surviving platforms from the Drucker collection has a distinct mat impression as a result of being flattened out on a woven mat during its manufacture. This platform, as well as others, is blackened on its upper surface, presumably due to burning incense there. Air vents are also present on the bodies of these vessels.

An appliquéd horizontal band that is thumb-impressed encircles each of the rims (Figure 8). Apparently both the upper and lower rims were similarly decorated. In most of these vessels the projections (i. e., spikes) cover the whole circumference except for the 'back', which is smooth and undecorated. In one specimen the spikes protrude about $1.5 \mathrm{~cm}$ from the vessel body. Thin vertical flanges, between two to four $\mathrm{cm}$ wide, separate the decorated zone from the undecorated one. In another case, however, the vessel has spikes over its entire exterior surface and lacks vertical flanges. Traces of white paint or lime occur on the exteriors of these vessels, making it clear that they were originally white. White-washing censers was a widespread practice throughout Mesoamerica, and continues to be carried on today by the Lacandon Maya. The meaning of this custom is not known. It is noteworthy, however, that Maya glyphs often refer to censers as sak lak or "white plate." Drum-shaped censers at Copán were called sak lak tun or "white stone plate" (Rice 1999:26). Similarly, the spiked censer portrayed in the Borgia codex (Figure 7) is white.

We suspect that at least some of these vessels were displayed against a wall or some other backdrop, based on the observation that their "backs" are undecorated. This possibility that they were designed for frontal viewing is supported by the observation that the Templo Mayor in Tenochtitlan had spiked hourglass shaped braziers incorporated as architectural features or embellishments (Matos Moctezuma 1987:Figure 5; Townsend 1987:Figure 4). These braziers, constructed of stone and plaster, are located close to risers of ascending terraces and therefore could only be appreciated from the front. The Aztec braziers lack flanges and the protuberances are nodular rather than spiked, but the general resemblance to the Las Delicias censers is unmistakable. Other stone braziers incorporated into the architecture of the Templo Mayor have effigies of Tlaloc, the Aztec rain god (e.g., Heyden 1987: Figure 10; Matos Moctezuma 1987:Figure 6). This is noteworthy for our study because the Las Delicias assemblage also has effigies of Tlaloc (see below).

Various meanings have been proposed to explain the symbolism of the appliqué spikes on Mesoamerican censers (Deal 1982: 619-620; Rice 1999:34). Kidder (1950:49) proposed what remains as the most popular explanation: spikes depict the thorns on trunks of young trees of the genus Ceiba. We favor this explanation because the spikes on the censers discussed here strongly resemble ceiba thorns in their size, shape and distribution. In the Maya area the ceiba tree was often worshipped along with the rain gods (Chacs, the Maya equivalent of Tlalocs) as symbols of abundance (Deal 1982:620) and even today farmers in southern Mesoamerica preferentially spare ceibas when clearing their fields. Two species in the genus Ceiba occur on the Pacific coast of Chiapas according to Pennington and Sarukhan (1998) and both form small thorny projections on their trunks, particularly when the trees are young. Both species also occur in the Maya area although their distribution is not isomorphic (Pennington and Sarukhán 1998:370-373). Probably the Maya considered both species of Ceiba to be sacred as both are referred to as yaxche ("green tree") (Pennington and Sarukhán 1998:370-373). Thompson (1970:177), however, thought that only C. pentandra was considered sacred. In any case, as Rice (1999:34) notes, the presence of these thorns on ceibas has lent support to the idea that the spiked censers evoke "the sacred 'first' or 'world tree' and axis mundi of the Maya cosmos."

Because the spiked censers from Las Delicias were originally large, heavy and very fragile, it is obvious that they were intended to be stationary like those of the Templo Mayor, and unlike the portable ladle censers described above. We think it likely that the spiked censers often were used in conjunction with the ladle censers as described in the first citation given above from the Florentine Codex, referring to the Mexica, and as depicted in the Borgia Codex referring to the eastern Nahua (Figure 7). At least the slim evidence points to this conclusion for two Late Postclassic period societies in central Mexico. This inference that the spiked censers in the Drucker collection are "braziers" is supported by artistic representations of smoking spiked censers on carved stone monuments at Izapa (Stela 5 [Norman 1973: Plate 9]), and Stela 24 (Norman 1973:Plates 39, 40) and Kaminaljuyu (Stela 11 [Guernsey 2006:Figure 3.8]) (see also Lowe 1965; cf. Guernsey 2006:Figure 3.9; Norman 1976:77) that date to the Late Preclassic period. The five spiked censers depicted on these three monuments support shallow dishes (Lowe 1965; cf. Guernsey 2006:Figure 3.9) and are most accurately described as censer stands. However, the Las Delicias objects, which were made and used much later, appear to have functioned without accompanying dishes.

We mentioned above that spiked incense burners of differing forms are widespread in time and space in Mesoamerica (Agrinier 1978:33ff; Rice 1999:31ff). It is significant for the present discussion that spiked censers were found in the mass burial context at Miramar (Agrinier 1978:29ff), and in the ceremonial dump (Susanna Ekholm, personal communication 2007) at Lagartero (Blake et al. 2005:433), both of which we described above. Some of the vessels from Miramar are generally similar in size and 
shape to those from Las Delicias but the spiked vessels from Lagartero are smaller jars, dishes and bowls (Blake et al. 2005: 431ff). Deep dishes with outslanting sides and exterior spikes were recovered from the cenote at Chinkultic, in the Chiapas highlands (Ball 1980:65) and one such vessel is shown in a bloodletting ceremony from Bonampak (Deal 1982:623). The Chinkultic spiked vessels have cruciform holes in the sides presumably to function as vents, and are fire-blackened in their interiors. At Izapa deep dishes with outslanting sides, thick walls, and exterior spikes have been recovered archaeologically (Norman 1976:77, Figure 2.40). The depictions of spiked braziers on stone monuments from Izapa and Kaminaljuyu also show vent holes but their shapes are different from those at Chinkultic.

Within the Proyecto Soconusco study area Voorhies (1989; Voorhies and Gasco 2004) found potsherds with spikes from large censers at Rancho Alegre (CAP-55), Las Morenas (MAP-5), and Acapetahua (CAP-1) where they were included in general trash deposits. In the last mentioned site these sherds came from both the Classic and Late Postclassic areas of the site (Voorhies and Gasco 2004).

In summary, there is a strong and enduring association between spiked vessels and ritual activity, particularly the burning of incense, as we noted previously. For example, Agrinier (1978:35) observes that spiked censers "continued to be an important part of the ceremonial inventory up to the time of Conquest." Deal (1982) discusses spiked censers among the modern Maya of highland Chiapas and we note further that even some present day "god pots" of the Lacandon Maya exhibit this plastic decoration (Voorhies, personal observation), as well as being rendered white by a coat of lime. Deal also observed that among the highland Maya spiked ceramic vessels are used today for ritual offerings of flowers. This observation cautions us to avoid assuming that all spiked vessels were once used as censers or censer stands. Nevertheless, the data reviewed are quite clear that over time and through space in southern Mesoamerica, vessels with appliquéd spikes are persistently used in ritual contexts.

\section{COLUMNAR CENSERS OR CENSER STANDS}

The Drucker collection contains one columnar censer or censer stand that is partially reconstructed, as well as some fragments apparently from a second one. The reconstructed object is a relatively slender hollow clay column (Figure 9) that is $78 \mathrm{~cm}$ high, but incomplete. The interior is divided into two chambers by a horizontal platform similar to those of the spiked vessels from the Drucker collection. The height of the vessel from rim to interior platform is $23 \mathrm{~cm}$. The diameter at the rim is $28.4 \mathrm{~cm}$. The vessel paste is coarse with medium-sized sand inclusions. It is tan in color with a grey fire core. Small patches of hematite are still visible on the exterior surface. One vertical flange has been refitted and extends along about $3 / 4$ ths of the vessel height. Air holes are present on two opposing sides. The second probable columnar censer or censer stand, which could not be refitted, has flanges that are $6.5 \mathrm{~cm}$ wide and a wide horizontal fan-like decoration attached to a pie crust decorated rim fragment.

The exterior surface of the reconstructed object is striated, giving it a texture resembling tree bark. This raises the possibility that the censer may have evoked a tree trunk similarly to the spikes on the braziers described above. Appliquéd bands encircle the circumference of the column at regular intervals. These bands are decorated alternately with incised, recumbent feathery chevrons and evenly

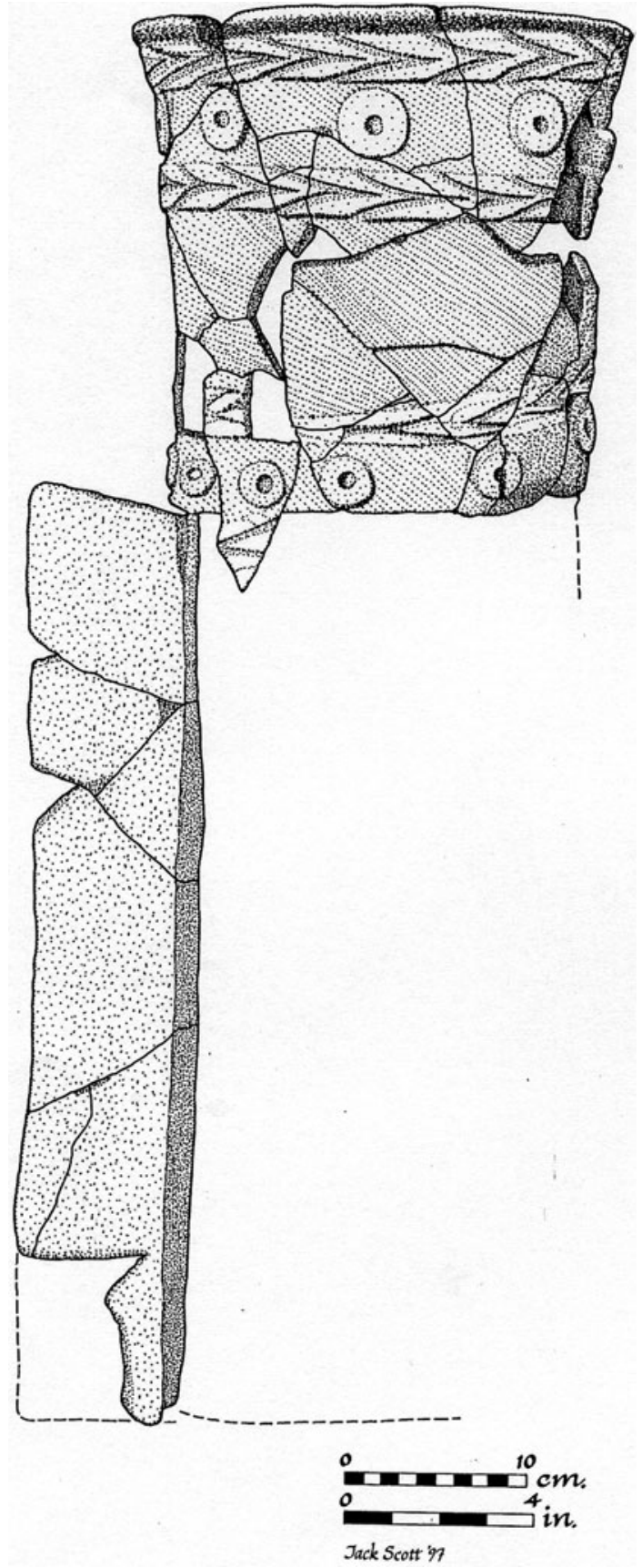

Figure 9. Drawing of a tall columnar censer or censer stand from Las Delicias that has been partially refitted. (Drawn by Jack Scott).

spaced clay disks (perhaps representing chalchiuhuitls, i.e., jade disks), starting at the rim with a band of chevrons. In ancient Mesoamerica both feathers and jade were considered to be precious materials. Some appendages resembling looped, knotted bows and knotted strips appear to be part of this vessel but we were unable to refit them to the body of the censer.

\section{NATURALISTIC ANTHROPOMORPHIC STATUE}

A partially refitted hollow item is very different in form from other objects in this collection and may be a portion of an 

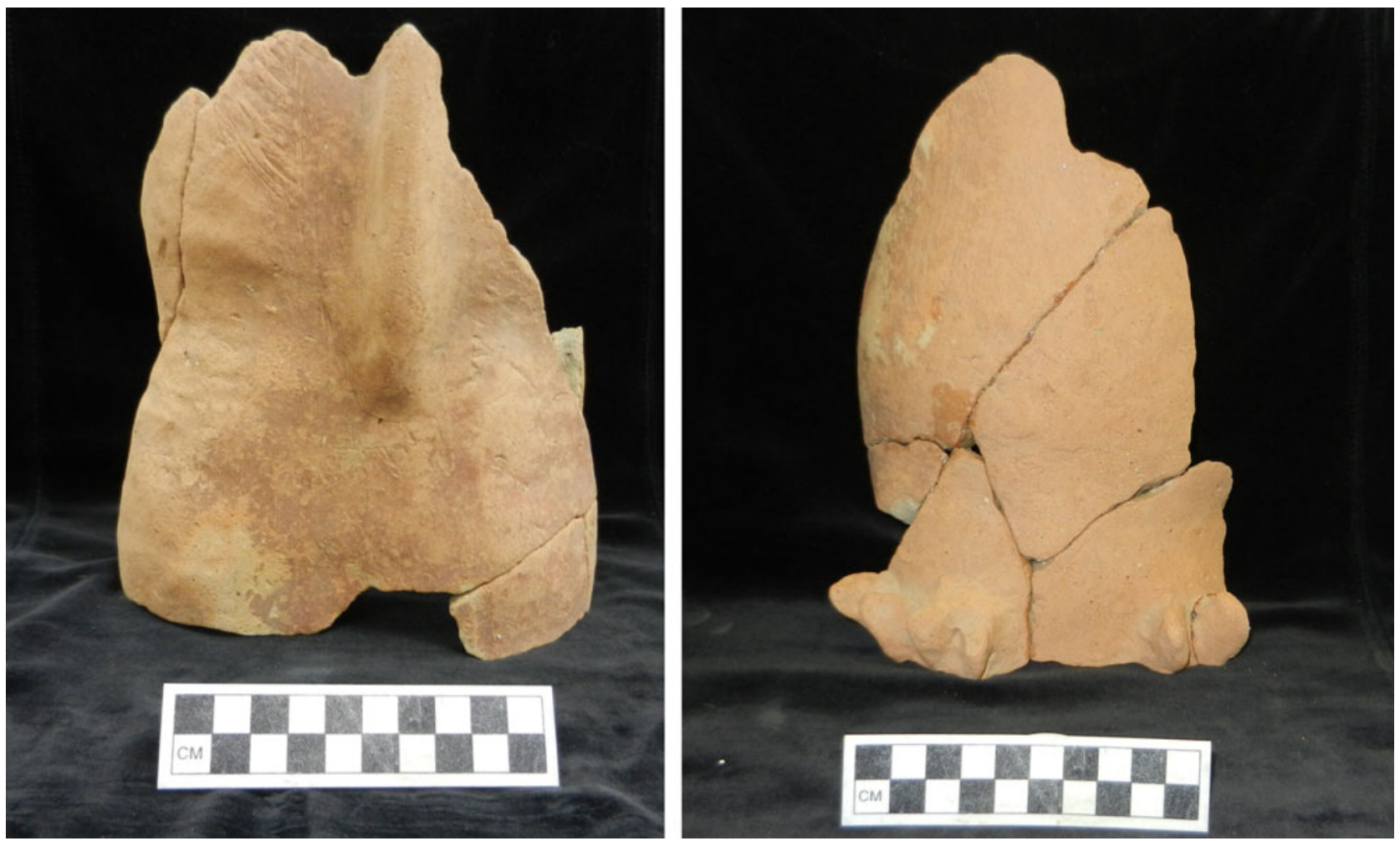

Figure 10. Photographs of two sides of a possible naturalistic anthropomorphic statue. (Photograph by Barbara Voorhies.)

anthropomorphic figurine. The surviving conjoined fragment is roughly cylindrical in shape, but is slightly flattened on two sides. The conjoined fragment provides a nearly complete circumference of the presumed statue with a hollow interior. The surviving piece is $20 \mathrm{~cm}$ in it longest dimension. We cannot determine the proper orientation of this item with any certainty, but think that it was oriented vertically, that is, with the hollow ends positioned upwards and downwards. We use this orientation in the following description.

On one flattened side of the object there is a centrally positioned modeled ridge that is parallel to the length of the cylinder but tapers out at one end (Figure 10a). This may represent a protuberant spinal column. Below the tapered end of the ridge but to either side, there is a swelling that is reminiscent of a person's lower back and the swell of buttocks. In other words, this side of the object strongly resembles a person's naked back. The opposite flattened side of the object (Figure 10b) slightly bulges out in the midsection of the conjoined fragment, below which there are two clusters of claw-like protuberances. There are four of these claws remaining on one side, but only two survive in the other cluster because of breakage. Among the unfitted sherds in the collection there is one piece with similar paste and a modeled ridge, and a second sherd bearing a cluster of claws. We were unable to join these fragments to the refitted object but they may be from the same item.

Like the other objects that we have described, this item is modeled out of a sand tempered paste that is thick walled $(1.0-1.5 \mathrm{~cm})$. The tan-colored interior surface has a rough texture with occasional overlapping clay layers and finger indentations resulting from the modeling technique. Clearly, this surface was not intended to be visible and provides one observation in support of the interpretation that the original object was a hollow statue. In contrast, the exterior has a smooth surface, is brick red in color and remnants of a red colored slip are clearly visible. There is no plastic decoration on this surface that is suggestive of fur or hair although in a few areas shallow, thin, parallel striations were made with a sharp pointed, multipronged instrument. Originally these striations probably would have been obscured by the red slip.

It is tempting to consider this statue as an example of the objects referred variously in the colonial literature as "idols," "demons" or "devils." Tozzer's commentary on the sixteenth century practices of the Yucatec Maya makes it clear that at least in some cases the "idols" are distinct from braziers (Tozzer 1966:110, n. 502), with which they are sometimes confused. In speaking of the Uayeb rites celebrated at the end of the solar year, Tozzer notes "the image, we are told, is a hollow figure of clay." Although the literature does not really permit us to determine the exact nature of the images venerated by the Yucatec Maya in the sixteenth century, Tozzer (1966:108) shows conclusively that idols ranged greatly in size and were very abundant.

It is noteworthy that in the illustration accompanying Sahagún's description of the Aztec disposal of household goods at the end of a calendric cycle a life-sized anthropomorphic statue is portrayed (Figure 5). The accompanying text specifies that the statue would have been either wood or stone but elsewhere in the Florentine Codex clay statues are mentioned. In fact, this refitted object is reminiscent of the pair of Eagle Warrior ceramic statues excavated near the Templo Mayor in Mexico City (e.g., Pohl and Lyons 2010:Plate XXVIII) that depict a human, probably a warrior, in a bird costume. The resemblance, albeit slight, includes the smooth unadorned back of the statue and the clusters of claws. However, the claws on the Eagle Warriors occur on the upper shins, whereas those of the object from Las Delicias appear to be on the torso of the object. 


\section{ANTHROPOMORPHIC SEATED EFFIGY BRAZIERS}

Drucker's collection from Las Delicias contains the remains of at least five and possibly six original effigy braziers or censers. These objects are basically large hollow cylinders with slightly outflaring rims, onto each of which a seated human form was modeled. Each of these braziers has an interior horizontal platform on which burning, presumably of incense, took place. The objects are made of coarse tempered, low-fired paste like the paste used for the large, spiked censers already described.

There are six partially refitted objects in the assemblage (one is now housed in the collections at the New World Archaeological Foundation, San Cristóbal de las Casas, Chiapas, Mexico), but we are unable to reconstruct any one of these vessels in its entirety. Three of the objects are from the lower portion of the original vessel, whereas three are from the upper portion. The uncertainty about the number of original vessels derives from the fact that it is conceivable that at least one lower section and one upper section are from the same original vessel, but we are unable to determine whether or not this is the case. We are confident, however, that these surviving fragments derive from censers depicting the same basic motif: a seated masculine individual, probably a dignitary or deity, wearing a crocodilian headdress or helmet. We describe these objects below. For simplicity, we have given each object a number.

\section{Effigy Vessel 1 (Figure 11)}

The most complete of the five effigy censer fragments is intact from its circular base to the shoulders of the effigy, but the head is missing. We have not examined this censer, but Drucker (1948:Figure 11a) included its photograph in his 1948

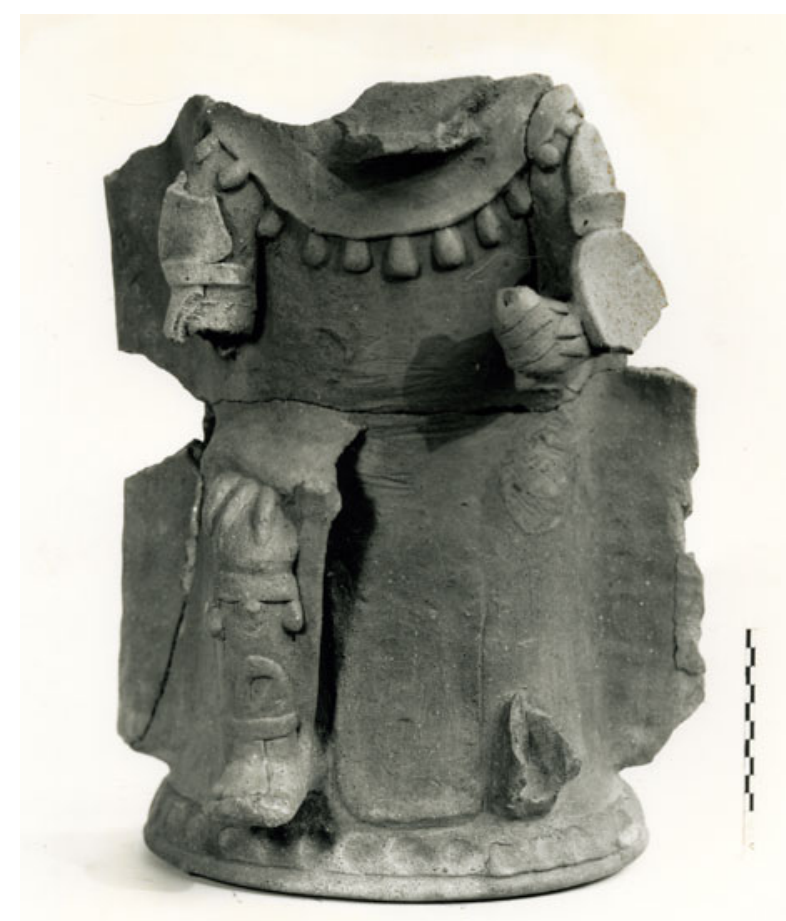

Figure 11. Photograph of partially refitted Effigy Vessel 1 from Las Delicias. Photograph by Philip Drucker (1948:Figure 1la). National Anthropological Archives, Smithsonian Institution (unnumbered negative). article and we reproduce it here. Since it did not arrive with the study collection sent to Voorhies, nor is it curated at the Smithsonian, we surmise that Drucker encountered it in a local collection where he took the photograph. As we mentioned above, the object is basically a large hollow cylinder onto which the features of the effigy have been modeled. The upper arms and the individual's right leg have survived, but the left leg is missing entirely, although the appliqué scars are visible at the position of the hip and foot where the missing leg was attached to the body of the cylinder. Both upper arms are sheathed in some kind of arm guard, and in addition the left forearm sports a circular concave disk. Next to this disk is a broken rounded or possibly cylindrical object that might be grasped in the left hand if the three strips around the object represent fingers. It is difficult to determine from examination of the photograph alone if fingers are depicted. A thick slab of clay is draped over the right thigh from which dangle three pointed objects resembling large claws. It is likely that this represents an animal pelt, possibly that of a feline judging from the claws. A horizontal strap with three dangling teardrop shaped objects binds the leg just below the knee. On the lower shin a vertical loop is bound to the ankle by a horizontal band. This may be part of the footgear of this individual. A broad undecorated loincloth (maxtlatl) is depicted between the individual's legs. It reaches to his feet. The rim of the censer base is finger impressed in the piecrust manner typical of the cylindrical censers in this collection. The individual is also wearing a bib-like chest ornament from which dangle more teardrop-shaped objects, presumably beads. Vertical plain flanges with straight edges flank the effigy from the level of the feet to the shoulders.

Our assertion that only one motif is depicted on these fragmentary effigy censers stems from a crucial observation on this vessel. Clearly visible on the individual's upper chest is an arcuate-shaped fracture scar where a projecting element was originally present. We are confident that this scar is where the mandible of a crocodilian headdress, similar to those we describe in Effigy Vessels 3, 4 and 5 , had broken off the main portion of the brazier. This strongly suggests to us that this individual, like the others, was wearing a crocodilian headdress.

\section{Effigy Vessel 2 (not illustrated)}

Effigy Vessel 2 is the bottom portion of a second censer virtually identical to the one just described. The vessel is hollow but it had an interior platform that was $29 \mathrm{~cm}$ above the basal rim, although only its edge survives. We refitted the entire circumference of the basal rim, along with the lower part of the loincloth and the lower portions of the vertical flanges. The basal rim is $30.5 \mathrm{~cm}$ in diameter and its exterior is decorated with a finger-impressed fillet. The loincloth flap is modeled in low relief but is undecorated. The vertical flanges are positioned on opposite sides of the vessel and extend approximately $7.5 \mathrm{~cm}$ away from the vessel wall. Scars from where the feet once were attached to the cylinder are clearly present. The back of the vessel is undecorated except for a very light scoring that was produced with a comb-like object with small, sharp prongs. An air hole with a $5 \mathrm{~cm}$ diameter is positioned on the left immediately in front of the flange. The opposite side of the vessel is missing. Although most of this vessel was not recovered, what remains is identical to Effigy Vessel 1 so we think that these vessels may have been a matched pair. 


\section{Effigy Vessel 3 (not illustrated)}

The remains of this vessel are now housed at the New World Archaeological Foundation, San Cristóbal de las Casas, Chiapas, Mexico. The conserved fragment consists only of a basal rim, the circumference of which is about three quarters complete. The fringed end of a loincloth is modeled in low relief and the scar remains from where the modeled right leg broke off the cylinder. There is another scar on the opposite side of the vessel at the location where a vertical flange was presumably attached, based upon a comparison with Effigy Vessel 1. The diameter of the rim is approximately $42 \mathrm{~cm}$.

\section{Effigy Vessel 4 (Figure 12)}

The conserved fragment of Effigy Vessel 4 consists of the upper portion of the original hollow vessel and is approximately $53 \mathrm{~cm}$ high. The effigy consists of chest and shoulders of an individual with a head emerging from a crocodilian headdress. The back of the vessel is undecorated except for the typical piecrust edging on the rim, which has a diameter of approximately $28 \mathrm{~cm}$. There is a double scallop surrounding the eye and wide vertical flanges with scalloped edges flank the effigy. The flanges extend $9 \mathrm{~cm}$ away from the vessel body. Rice believes that the embellishment of censer side flanges may have iconographic significance. She notes "the edges of these flanges are sometimes ornamented with paired "loops" or nodes of glyph T87 (te, "wood tree") suggesting that even image censers, or censer stands, might have embodied some aspects of the axis mundi (Rice 1999:36). Rice observes that double scallops or nodes are often found on censer flanges (Rice 1999:Figure 8). Triple scallops can appear in the same context.

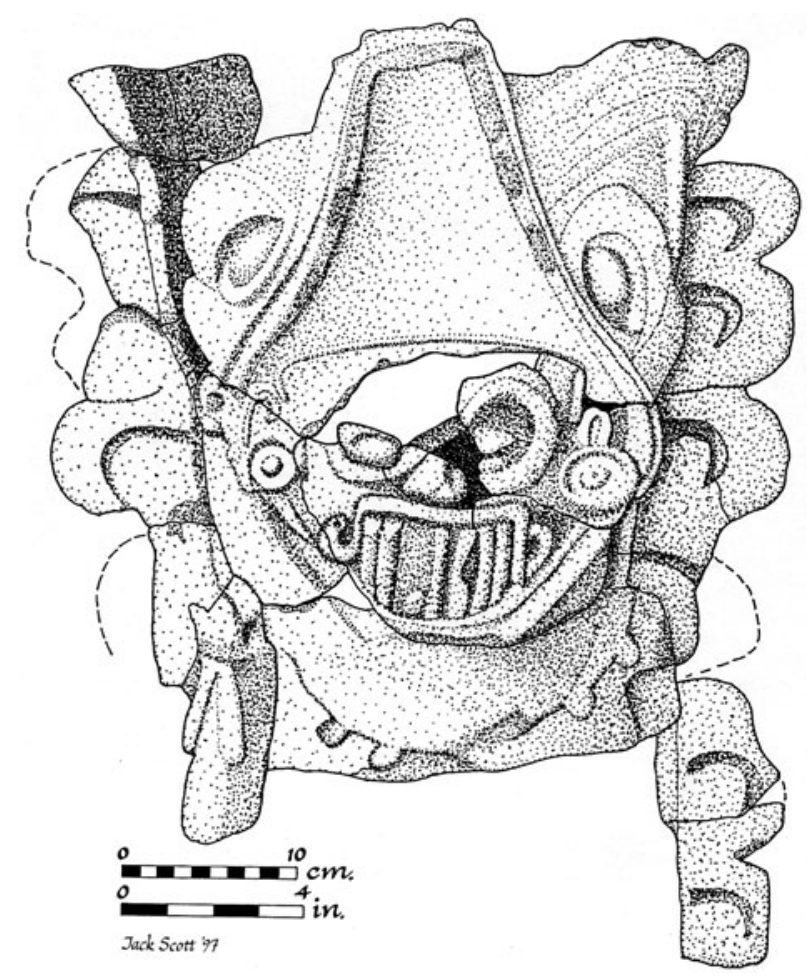

Figure 12. Drawing of partially refitted Effigy Vessel 4 from Las Delicias. (Drawn by Jack Scott.)
Andrews (1970:Figure 10b) reproduces a Tlaloc brazier with three-scallop flanges from the Balankanche cave in Yucatan.

The principal figure is wearing a bib-like chest ornament with teardrop beads, very similar to that of Effigy Vessel 1. The uppermost portion of the right arm has survived and it appears to have some kind of arm decoration or guard that terminates in two long streamers. A huge gaping crocodilian head surmounts the shoulders. Stumps of broken teeth remain along the jaw line, but at the right corner unbroken teeth are rectangular like human teeth, rather than conical as is true of crocodilian teeth. A slightly protruding scallop is beneath each of the large, half lidded eyes. The lower jaw is broken off but it once projected outward from the body of the vessel. Circular disks are modeled at the corners of the animal's mouth. This recalls the depiction of a crocodilian, also presumably a caiman, on Izapa Stela 25 (Guernsey 2006:Figure 3.17). On Altar T at Copán, a splayed crocodile is shown with paired discs at the intersection of the head and neck area and on the side of the altar a seated version of the same creature is shown wearing ear spools and other jewelry (Maudslay 1889-1902:Plates 95, 96). Thus we infer that the disks on Effigy Vessel 4 indicate ear spools.

A face depicted as the central Mexican deity Tlaloc emerges from the maw of the crocodilian. It is wearing a mouth mask consisting of seven long fangs and an upcurled moustache, which could be a snake because of its eye indentation. The left side of the Tlaloc face retains an original eye ring. It has human ears wearing round jade earplugs. A left side view of the face reveals that the nose appears human but is missing its tip.

The interior platform is heavily burned on its upper surface, which also bears an impression of a woven mat. The underside of the platform is smooth and unburned. The intact platform has a diameter of $22.5 \mathrm{~cm}$.

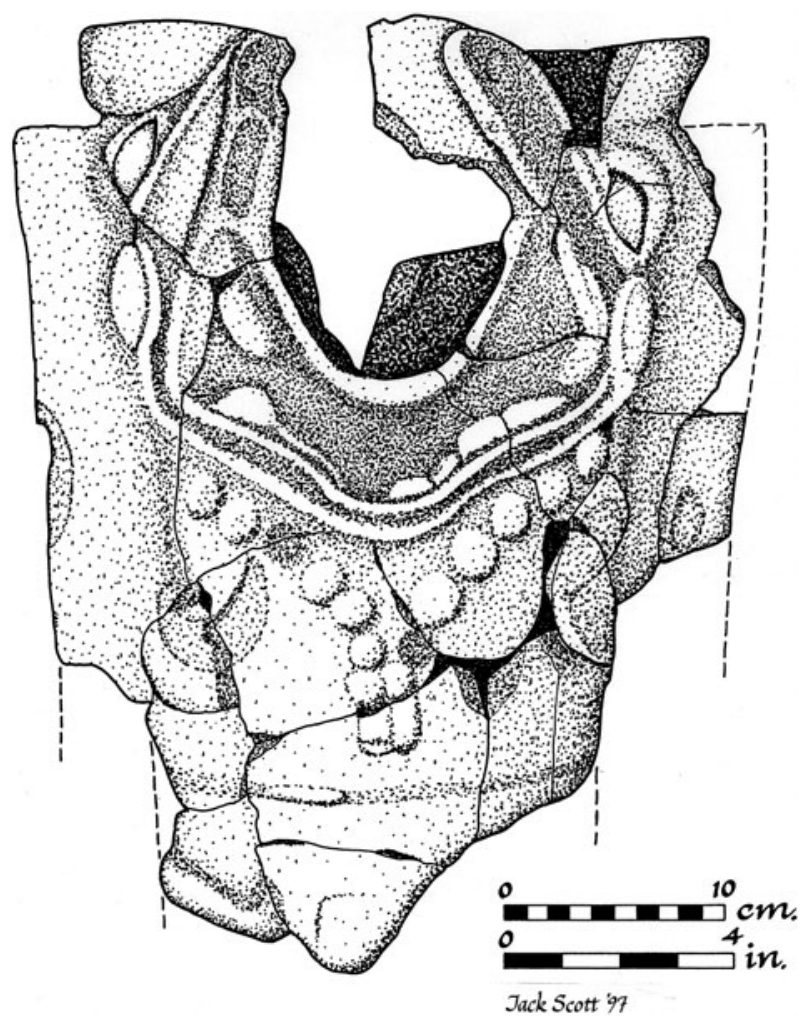

Figure 13. Drawing of partially refitted Effigy Vessel 5 from Las Delicias. (Drawn by Jack Scott). 


\section{Effigy Vessel 5 (Figure 13)}

The Effigy Vessel 5 fragment consists of the upper portion of a censer that extends from just below the waist level of the effigy to the upper rim. The surviving piece is approximately $43 \mathrm{~cm}$ high. The principal decoration consists of the open-mouthed crocodilian or earth monster comparable to that on the vessel just described. Here the lower jaw is more fully defined with rectangular teeth surviving intact along the bottom edge. The upper jaw also is edged with teeth and is upwardly thrusting similar to Effigy Vessel 4. Circular disks are depicted at both corners of the mouth. The heavy lidded crocodilian eyes are clearly modeled and end in a curl on either lateral side. The emergent face is missing, but it could have been one of the goggle-eyed censer faces from Las Delicias that were photographed by Drucker (1948:Figure 11a) while in the field. The figure wears a necklace of large round beads that terminates in a tassel at its lowest point. Scars where the arms were once attached are clearly visible on either side of the necklace. A clay band once encircled the torso at waist level but now only small remnants and an appliqué scar remain. The uppermost edge of the modeled loincloth may be seen at the lowest point of the conserved fragment. Two vertical flanges with straight edges flank the effigy until they terminate just below the upper rim. The surviving portion of the upper rim is decorated with piecrust impressions, probably made with a thumb, except in the front where the crocodilian upper jaw occurs. There, the rim band is plain with ends suggestive of a cloth headband. The rim diameter is about $24 \mathrm{~cm}$.

The interior platform is $29 \mathrm{~cm}$ below the rim. It is very heavily burned on the upper surface and has a diameter of $22 \mathrm{~cm}$.

\section{Effigy Vessel 6 (Figure 14)}

The Effigy Vessel 6 fragment consists of the refitted gaping maw of a crocodilian headdress and the upper rim of the original censer. We estimated the rim diameter to be $26 \mathrm{~cm}$ and the refitted piece is $27 \mathrm{~cm}$ high. The crocodilian's eyes are present and are surmounted by eyebrows with scalloped edges that protrude slightly above the vessel's rim. Occasional surviving triangular teeth edge both jaws and circular disks with cloth-like strips hanging from their centers, are depicted at both corners of the mouth. A thin tonguelike vertical strip is on the chin, and although broken, originally draped over the lower jaw of the crocodilian helmet. The emergent face is largely destroyed but an appliquéd strip shaped as a curl on the left side of where the mouth would have been looks very much like the end of a moustache of a Tlaloc mask.

\section{Discussion of Effigy Censers}

In this section we consider the style and iconography of the effigy censers from Las Delicias within the broader context of Mesoamerican censer forms and their meaning. First, a few words are in order regarding the shift in our understanding of Maya (and Mesoamerican) creation mythology that resulted from pioneering investigations presented in Maya Cosmos by Freidel, Schele and Parker (1993). The decipherment of key glyphs on Stela C from Quirigua and other texts led to the insight that the placing of three stones by creator gods at the center of the sky was a founding act in the Maya story of creation. This occurred on the creation date 13.0.0.0.0. 4 Ahau 8 Cumku. The three stones were the cosmic hearth and the center of all creation. It then became clear that the

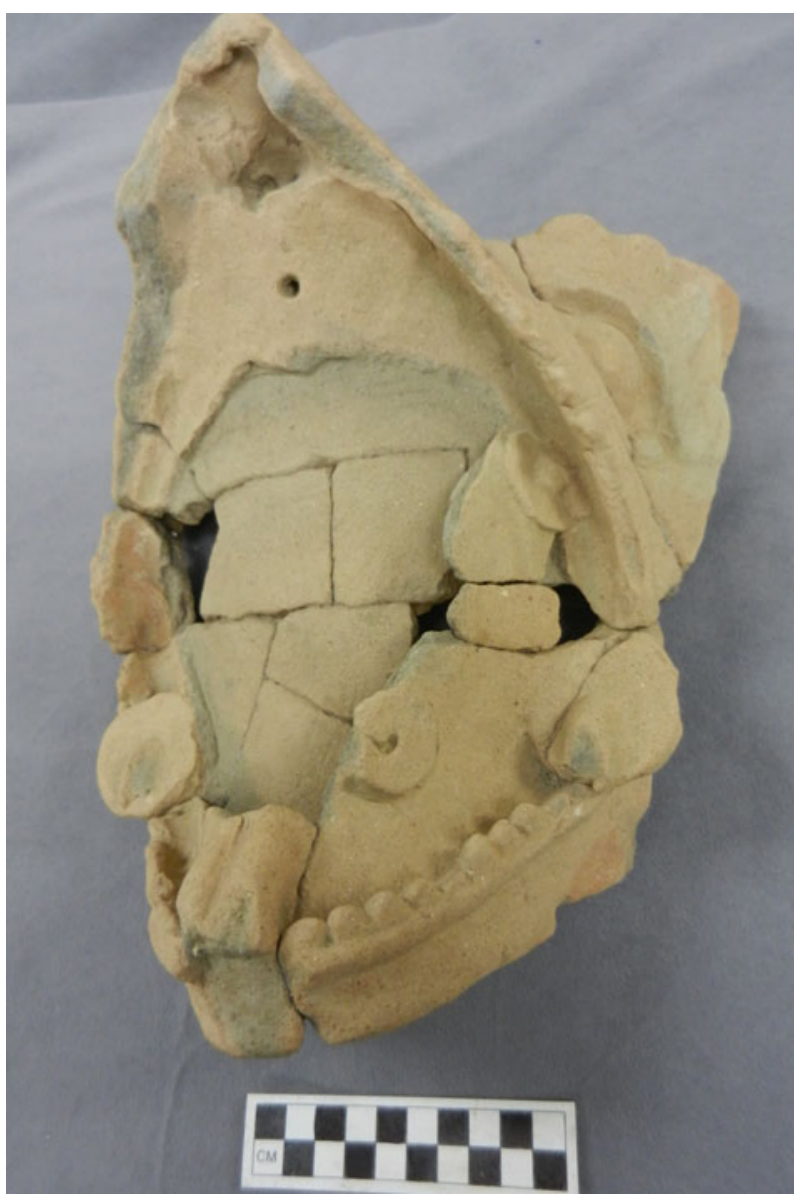

Figure 14. Photograph of partially refitted Effigy Vessel 6 from Las Delicias shown in oblique view. (Photograph by Barbara Voorhies.)

humble three-stone hearth of every Maya house was part of an extended metaphor for the sacred center that included the "First Mountain" as well as the World Tree that was raised above the hearth to separate the sky from the earth. The newly revealed iconography of the center conceived the World Tree as an axis mundi because "...the Maya thought of the entire north direction as a house erected at Creation with the World Tree, the Wakah-Chan, penetrating its central axis" (Freidel et al. 1993:71). These insights had enormous significance for the understanding of censer iconography because as scholars later would discuss in detail (e.g., Rice 1999; Taube 1998), for ritual purposes the ceramic censer/brazier was a stand-in for the sacred hearth.

The Las Delicias censers are fragmentary, but the surviving remains are consistent with this iconography of the center. On the effigy censers, at least three of the anthropomorphic figures are depicted wearing monster headdresses that appear crocodilian. In Mesoamerica, the crocodile was synonymous with the Earth Monster as well as with the World Tree. This metaphor is given explicit form on Izapa Stela 25, a Preclassic period monument, where a vertically oriented crocodilian is shown head down with the ascending hind legs morphing into leafy branches with a bird perched at the top (Freidel et al. 1993:137, Figure 4:25; Guernsey 2006:Figure 3.17). Thus the anthropomorphic deity or impersonator who is depicted on the Las Delicias censers wears helmets referencing this crocodilian creature. This refers to the creation of the world 
and by extension the creation of time and a new era within the context of our proposed period-ending ritual. It is also possible that the people at Las Delicias shared with the Aztec, and others, the custom of naming the first day in the 260-day count for the crocodile. For the Aztecs this day name was Cipatli, the Nahuatl word for crocodile or caiman.

In short, the appearance of the crocodilian Earth Monster on censers is logical and appropriate. However, our examples are more explicitly descriptive of the crocodile than many examples from other sites where the monster is rendered as an abbreviated mask. For example, Schmidt et al. (1998:Figure 317) illustrate a censer lid from Moxviquil, in highland Chiapas. A Late Classic example, it depicts a human face emerging from the "maw of a fantastic animal" that is not specifically crocodilian. In the Maya lowlands the motif of human faces emerging from the mouths of fantastic animals is quite well known. One late example from Lamanai, Belize is a ceramic effigy vessel of a "mythical crocodilian" with an emergent human face (Pendergast 2006:Figure 5.13; see also Graham 2011:208 ff) that was found in a cache buried within an early Christian church.

Tlaloc iconography is another significant motif on the effigy braziers of Las Delicias. The face on Effigy Vessel 4 wears the eye rings and fangs of the Central Mexican deity Tlaloc. Although this is the only surviving face on our effigy vessels it is likely that they all shared this characteristic. The closest visual comparison we are able to find is a Mixtec-style vessel from West Mexico considered to be Postclassic in age (Deletaille et al. 1992:Figure 129). This vessel is a tripod olla rather than a censer, but it features a human-bodied Tlaloc impersonator wearing a monster helmet (Figure 15). In addition, this figure wears a wrist disc similar to

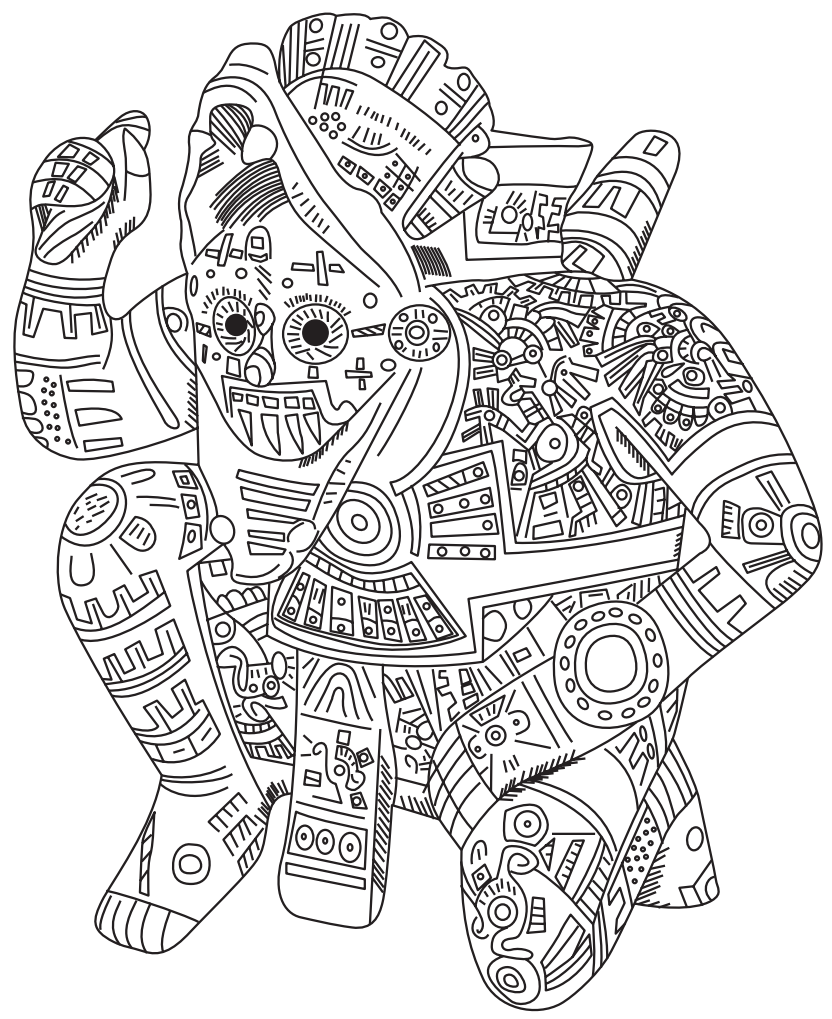

Figure 15. Mixtec-style Tlaloc effigy vessel from El Chanal, Colima, Postclassic in age (drawn by Dan Van Dorn from Deletaille et al. 1992:Figure 129). that worn by Effigy Vessel 1. He holds an unknown cylindrical object in the other hand. In contrast to the local flavor of the realistic crocodilian helmets, these Tlaloc attributes reflect influence from central Mexico.

The regalia worn by our effigy figures and the Mixtec Tlaloc of the olla may be usefully compared to page 26 of the facsimile edition, Codex Vindobonensis Mexicanus 1 (Anderhofer 1974:26) where eight Tlaloc impersonators attend a burning event. They wear beaded bib necklaces comparable to our Effigy Vessel 1, they have small ritual shields strapped to one arm and hold small (here tasseled) objects in the same gesture as the olla Tlaloc A.

Tlaloc is best known as the Central Mexican rain god whose most distinctive attribute is the goggles we see in our example (Figure 12). Tlaloc first appears in his iconic form at Teotihuacan where he is frequently depicted in murals and other media, and his iconographic attributes are regarded as markers for Teotihuacan contact and/or influence in other areas of Mesoamerica during the Classic period before the city's collapse. It is fair to say that the iconography of Tlaloc was among the most influential of Teotihuacan artistic exports and other Mesoamerican people appropriated his iconography for different purposes. While greatest attention has been paid to examples in the Maya lowlands and the Chiapas highlands, the Mixe Zoquean area, where Las Delicias is located, was not immune to this influence. For example, Tlaloc is depicted in full regalia as a calendric rain deity on Stela 3 from Los Horcones (Garcia Des-Lauriers 2005, 2007; Urcid 2005:Figure 7.11), an Early Classic period site also on the coast of Chiapas where Teotihuacan contact appears to have been very direct.

While some of the borrowings by Maya elites reflect appropriation in service of dynastic state art, our effigy censers found at a small, undistinguished site, appear to reflect appropriation in the service of a cult. Our examples are Late Classic in age, postdating the apogee of Teotihuacan's political influence and they are not the result of direct contact with Teotihuacan. They may be part of a wide phenomenon whereby cylinder censers decorated with the face of Tlaloc became popular in much of Mesoamerica during the terminal Classic and Postclassic periods after the decline of Teotihuacan. Prudence Rice has proposed such a scenario when considering incensarios from the Maya sites of Altar de Sacrificios, Caracol and Balankanche cave: "In the northern lowlands, the terminal Classic shift in censer types has been linked to the spread of a Mexican-inspired Quetzalcoatl cult ... which featured the use of ladle, open-work, spiked hourglass and Chac/ Tlaloc censers" (Rice 1999:39).

In order to put this development into perspective, it is important to point out that Tlaloc is not represented as a central deity on braziers or censers at Teotihuacan. This function usually falls to an aged god on the stone braziers and a youthful deity on the composite censers. The latter is generally depicted in the form of a mask and has been interpreted as a butterfly, warrior deity. While López Luján (2006:Figure 134a) includes a cylinder vessel from Yayahuala, Teotihuacan among his illustrations of Tlaloc burners, the eyes are feathered rings and we consider the identification with Tlaloc to be suppositional. On the other hand, composite censers at Teotihuacan have adornos (decorative elements) that contain symbolism connectable to Tlaloc (Berlo 1984:Plate 37; Langley 1997). By Late Classic times, Tlaloc faces begin to appear on cylinder censers outside of Teotihuacan. For example, representations of Tlaloc on cylinder censers were excavated from Lake Amatitlán, Guatemala (Berlo 1984:Plates 243, 244). These 
include a human face wearing eye rings and the abstracted Tlaloc faces that characterize the above-noted censers described by Rice.

The popularity of a foreign rain god among the Maya and other Mesoamerican peoples is not well understood and is often attributed to the prestige and power of Teotihuacan, as well as the critical importance of rain in agrarian societies with rain-based agricultural systems. However, it is important to note that Tlaloc was far more than a rain god and better explanations for his significance here are likely to be found in the multifaceted nature of his persona, and his appearance in contexts not directly connected to rain. Cecelia Klein addressed this issue in Who was Tlaloc? (1980), pointing out that the representations of Tlaloc in Aztec art and native pictorials reveal a far more complex deity than is found in the chronicle accounts usually consulted by scholars.

Klein noted that Tlaloc's complexity is already evident at Teotihuacan where he was a hybrid deity variously combining human aspects with characteristics of the Izapan crocodilian earth monster and the Night Sun jaguar (Esther Pasztory's [1974] Tlalocs A and B). In addition, from Teotihuacan through Aztec times Tlaloc was depicted in contexts signaling his linkage to the cosmic center. He was also a calendar deity connected with the computation of time who presided over period ending celebrations. In Mesoamerica, endings are also beginnings: "Tlaloc's critical position in the Mesoamerican calendar as patron of the final year and quarter of the 52-year cycle," meant that he was "host and augur of the incoming century" (Klein 1980:182). Consistent with his importance at beginnings, Tlaloc "appears at the beginning of three of the four Mixtec genealogical manuscripts (Nuttall, Vindobonensis reverse, and Bodley) as the founder of all the important lineages involved there" (Klein 1980:173). This is very interesting because this is how the iconography of Tlaloc is used at Copan where the founding dynast, Yax Kuk Mo, is depicted on monuments wearing Tlaloc goggles (Maudslay 1889-1902:Plate 92).

Representations of ceremonies in the Borgia Codex (Díaz and Rodgers 1993:28) show Tlaloc as a patron of the final period of the Venus/solar cycle. Tlaloc was particularly linked with solar cycles and he often wore a year sign in his headdress. This role appears to derive from his jaguar/solar associations. Klein (1980) notes the synchronicity between jaguar Tlaloc, and the Maya jaguar god of the underworld (JGU), who was also the Night Sun - the very entity whose image is most frequently represented on Maya censers (Goldstein 1977; Rice 1999:36). In these censers JGU is depicted at the conceptual axis mundi, often appearing in the jaws of a jaguar or earth monster or as a jaguar giving birth to a cub from his own jaws.

Jaguar Tlaloc B is usually depicted with a curled moustache and straight fangs, and that is consistent with the mouth mask on Effigy Vessel 4 (Figure 12). We do not know whether all of the figures on our censers wore Tlaloc goggles and mouth masks but it is probable many did. As we mentioned, the costume elements on the censer fragments that have been refitted are consistent with such a possibility. Also, as mentioned, Drucker (1948:Figure 11) illustrates two Tlaloc faces from Las Delicias that were in local collections but may have come from censers.

Other attributes connected to Tlaloc that can be seen on our censers include the long loincloth, the possible jaguar pelt (visible on Effigy Vessel 1), the bib collar with the pendant beads that is visible in two examples (compare Klein 1980:Figure 8b), and the large round beads, presumably jade, visible in Effigy Vessel 5 (Figure 13). Jade beads were considered "precious"; they connoted fertility and riches, and they were almost certainly connected with the counting of time. For example, numerical digits often were represented as jade beads in the Mexican number signs.

Tlaloc censers were sometimes created as groups. For example, Boggs (1949) reported a Postclassic censer set from El Salvador consisting of five cylinder censers decorated with human bodied Tlalocs, each wearing a different pectoral. It seems likely that such censer sets were set up in a directional arrangement because Tlaloc also was associated with the four directions and the center. "During the Aztec month festival etzalcualiztli..., which was dedicated to Tlaloc, an enormous tree was set up in the ceremonial center amidst a bevy of smaller trees four of which like the Tlaloque were arranged at the cardinal directions .... Since the etzalcualiztli rite implies that the tree itself was a representation of Tlaloc .... It is significant that it was addressed as tota, 'Our Father' because says Durán, it seem(ed) to be the father of the others" (Klein 1980:174).

\section{DISCUSSION}

We propose that the items disinterred by Drucker from an excavation in the plaza of Las Delicias, Chiapas, constitute ritual paraphernalia and domestic items that were most likely intentionally discarded at a calendric cycle ending, exactly as Drucker originally proposed in his 1948 article. We make this argument based in part upon the archaeological context of the assemblage.

This is neither the first nor the only situation in which archaeologists have claimed that they have uncovered the material signatures of ceremonial dumps, like those reported in the ethnohistoric literature. Two examples predating the Postclassic period are present in the known archaeological record from Chiapas-from Miramar and Lagartero. Both deposits were found in plazas and contained ritual and utilitarian items, so they meet at least some of the expected criteria of a ceremonial deposit.

The depositional situation at Miramar is complex and difficult to fully comprehend from the available report (Agrinier 1978). An initial offering of ceramic vessels was deposited after which human sacrifices took place. The excavator thinks the victims may have been dispatched on the spot, but if not, judging from their positions they must have been thrown into the pit immediately after death. Finally, an extensive offering including ritual items was deposited directly above the mass burial. This offering also included miniature tecomates and utilitarian ceramic vessels. The published report is not clear about when this final offering occurred, other than noting it was after the victims' execution. Agrinier (1978:47) seems to think it reflects the arrival of new people at the end of the Middle Classic period but he also states that Late Postclassic sherds occur in the stratum underlying this deposit but with no further explication about how they got there (Agrinier 1978:23). This observation at least raises the possibility that the final offering or dump dates to the Late Postclassic period.

The Middle Classic sacrificial mass burial at Miramar was indisputably a ritual event although it cannot be tied to a particular calendric event; the excavator speculates that a solar eclipse may have inspired this sacrifice because a solar eclipse coincided with the general time period of the event (Agrinier 1978:21).

The Lagartero dump excavations have never been fully published but a brief description is available in Ekholm (1979). She describes the feature as a Tepeu 1-2 Horizon (i.e., Late Classic period) concentration of material measuring 24 by $10 \mathrm{~m}$ and about $2.5 \mathrm{~m}$ deep. About half a million potsherds were recovered from this feature, as well as many other artifacts. There was no natural stratigraphy within the feature and many objects coming from different 
parts of the feature could be refitted. It is quite certain that this was a single event of ritual nature and it corresponds very well to the protohistoric descriptions of end-of-cycle ritual events.

Elson and Smith (2001:159) credit Vaillant as proposing as early as the 1930s that certain archaeological deposits at sites in the Basin of Mexico provided tangible evidence of the end-of-cycle New Fire Ceremony. After careful evaluation of this evidence these authors propose that archaeological expectations of that ceremony, as it is described in the protohistoric literature, are met at three archaeological sites in the Basin of Mexico (Chiconautla, Nonoalco and Cuexcomate). In addition, Diane Chase (1985) has argued that the distribution of ritual items at the Late Postclassic period Maya site of Santa Rita Corozal, Belize, may reflect celebrations of annual New Year ceremonies. However, an actual ceremonial dump was not excavated at that site.

We cannot say for sure which period ending, if any, was being celebrated as Las Delicias. When Spaniards arrived in the early sixteenth century the two best described indigenous societies, the Aztecs of central Mexico and the Maya of Yucatan, both celebrated the solar year endings by ritually discarding utilitarian and specialized ritual items. This raises the possibility that the practice was pursued widely across Mesoamerica by many other groups, such as the native people of the Soconusco coast. It is also important to keep in mind that in Mesoamerica several calendric cycles were interwoven with the solar year, including the Venus/solar cycle of eight solar years, the 52-year cycle, and the 104-year Great Venus Round when the three most important calendar cycles ended together. Therefore, it is reasonable to speculate that ritual dumping may have accompanied multiple solar year endings such as these. Of these events, it is Venus/solar rituals that seem to have been most widely referred to in art in both southern and northern Mesoamerica on the monuments and in the codices.
As to the possible presence of a 52-year celebration at Las Delicias, we note Elson and Smith's (2001) proposition that the 52-year ritual celebration was invented at Xochicalco. If such were the case, the celebration might have been transmitted to Chiapas during the Late Classic period under Toltec influence from Late Classic sites like Xochicalco. This scenario is consistent with the Tlaloc references on the censers and it may reflect a phase of Toltec cultural influence in the area. It is striking that the Los Horcones Stela 3, which is stylistically influenced by Teotihuacan (Garcia-Des Lauriers 2007) exhibits a glyphic style that is similar to stelae at Xochicalco.

\section{CONCLUSIONS}

During an archaeological survey of the coast of Chiapas, Mexico, Philip Drucker excavated what he thought was a ceremonial dump, perhaps deposited at some calendric period ending, at a small, undistinguished platform mound site by the name of Las Delicias. In this paper we have revisited Drucker's archaeology at the site, described some of the objects that he excavated from the suspected ceremonial dump, and explored the significance and meaning of these items.

We have argued, following Elson and Smith (2001), that the archaeological context of this assemblage fits the criteria of expectations for a ceremonial deposit marking the end of a calendric cycle as described in the protohistoric literature for Mesoamerican societies. Moreover, we have seen that appropriation of Tlaloc iconography for the decoration of effigy censers is consistent with, and strongly supports, the notion that these objects were deposed in a period ending ritual. However, we have been able to only speculate what period ending may have been celebrated.

\section{RESUMEN}

En 1947 durante un reconocimiento arqueológico en la costa de Chiapas, México, Philip Drucker excavó una concentración densa de artefactos en la plaza de Las Delicias, un sitio pequeño que pertenece al clásico tardío. Este hallazgo consistió de artefactos rituales como incensarios, junto con una variedad de objetos utilitarios. Drucker postuló haber encontrado un basurero en donde los habitantes descartaron todos sus enseres usados en un evento ritual, posiblemente durante las celebraciones de un fin-de-ciclo. Él pensó eso debido a que la evidencia arqueológica indica que todo el material, incluyendo objetos completos pero quebrados en pedazos grandes, han sido depositados en un solo evento. En el presente articulo, los autores describen el sitio de Las Delicias, el depósito excavado por Drucker y algunos artefactos rituales que fueron llevados al Smithsonian Institution y que todavía están disponibles para su estudio. Estos objetos son incensarios con cabos largos, braseros con decoración de espigas, un incensario o soporte cilíndrico, una estatua antropomórfica y varios braseros con efigies antropomórficas. Los objetos utilitarios no fueron discutidos por Drucker y tampoco sobrevivieron para ser estudiados hoy día.
Además, los autores analizan la iconografía de los braseros con efigies antropomórficas. Se trata de un personaje un Señor o dios masculino sentado con un maxtlatl largo y con casco en forma de cabeza de cocodrilo. La cara del Señor aparece en la boca del cocodrilo y tiene el aspecto del dios Tláloc. Estos motivos artísticos son metafóricamente lógicos porque indican que los braseros son simbólicos del centro cósmico (el cocodrilo como equivalente del árbol del mundo) y que Tlaloc es un dios con muchos aspectos incluyendo los calendáricos. Pero básicamente los incensarios con efigies nos indican que los habitantes en un pequeño sitio costero participaron en un culto del dios Tlaloc muy extendido geográficamente.

Finalmente, los autores presentan las expectativas que un arqueólogo debería tener para reconocer un basurero ritual de fin-de-ciclo. Las expectativas se basan en los escritos etnohistóricos de la época colonial sobre los ritos. Los autores concluyen que el depósito de Las Delicias se ajusta muy bien con estas expectativas arqueológicas y por eso están de acuerdo con que Drucker encontró un basurero ritual que podría haber sido parte de una conmemoración de fin-de-ciclo.

\section{ACKNOWLEDGEMENTS}

We are grateful to the late Clifford Evans for providing us with the opportunity to study the artifacts from Las Delicias. We would also like to thank Linda Pfeiffer, at the time a graduate student at the University of California, Santa Barbara for her work on analyzing the Drucker collection, and to
Tracy Sweely, then a graduate student at the University of Colorado, Boulder, for her written descriptions of this material. Pfeiffer's work was funded by a General Research Grant to Voorhies from the Academic Senate at the University of California, Santa Barbara. Jack Scott provided 
accurate and aesthetically pleasing drawings of three of the partially refitted censers. We are especially grateful for his expertise and artistic talent. Aura de Anda and Dan Van Dorn each drew several illustrations and Becky Alvarez and Miguel Pavía edited the Resumen. We thank Ronald Bishop for his help in our attempt to locate some of Drucker's original material at the Smithsonian Institution and for temporarily caring for these

\section{REFERENCES}

Adelhofer, Otto (editor)

1974 Codex Vindobonensis Mexicanus 1, Österreichische Nationalbibliotechek Wien. Akademische Druck - u. Verlagsanstalt, Graz, Austria. Electronic document, http://www.famsi.org/research/ graz/vindobonensis/img_page26.html, accessed March 29, 2016.

Agrinier, Pierre

1978 A Sacrificial Mass Burial at Miramar, Chiapas, Mexico. Papers of the New World Archaeological Foundation, No. 42. Brigham Young University, Provo.

Andrews IV, E. Wyllys

1970 Balankanche, Throne of the Tiger Priest. Middle American Research Institute Publication No. 32. Tulane University, New Orleans.

Ball, Joseph W.

1980 The Archaeological Ceramics of Chinkultic, Chiapas, Mexico. Papers of the New World Archaeological Foundation, No. 43. Brigham Young University, Provo.

Ball, Joseph W., and Jennifer T. Taschek

2007 Sometimes a "Stove" is "Just a Stove": A Context-Based Reconsideration of Three-Prong "Incense Burners" from the Western Belize Valley. Latin American Antiquity 18:451-470.

Berlo, Janet Catherine

1984 Teotihuacan Art Abroad: A Study of Metropolitan Style and Provincial Transformation in Incensario Workshops. BAR International Series 199. British Archaeological Reports, Oxford.

Blake, Michael, Douglas Donne Bryant, Thomas A. Lee Jr., Pierre Agrinier, and Susanna M. Ekholm

2005 Late Classic Ceramics. In Ceramic Sequence of the Upper Grijalva Region, Chiapas, Mexico, Part 2, edited by Douglas Donne Bryant, John E. Clark, and David Cheetham, pp. 415-547. Papers of the New World Archaeological Foundation, No. 67. Brigham Young University, Provo.

Boggs, Stanley H.

1949 Tlaloc Incensarios in the Baratta Collection, El Salvador. Notes on Middle American Archaeology and Ethnology, No. 94. Carnegie Institution of Washington, Washington, DC.

Borhegyi, Stephan F. de

1951a A Study of Three-Pronged Incense Burners from Guatemala and Adjacent Areas. Notes on Middle American Archaeology and Ethnology, No. 101. Carnegie Institution of Washington, Washington, DC.

1951b Further Notes on Three-Pronged Incense Burners and Rim Headed Vessels in Guatemala. Notes on Middle American Archaeology and Ethnology, No. 105. Carnegie Institution of Washington, Washington, DC.

Chase, Diane Z

1985 Ganned but not Forgotten: Late Postclassic Archaeology and Ritual at Santa Rita Corozal, Belize. In The Lowland Maya Postclassic, edited by Arlen F. Chase and Prudence M. Rice, pp. 104-125. University of Texas Press, Austin.

Clark, John E., Thomas A. Lee Jr., and Douglas Donne Bryant

2005 Introducing the Grijalva Maya Project. In Ceramic Sequence of the Upper Grijalva Region, Chiapas, Mexico, Part 1, edited by Douglas Donne Bryant, John E. Clark, and David Cheetham, pp. 1-20. Papers of the New World Archaeological Foundation, No. 67. Brigham Young University, Provo.

Deal, Michael

1982 Functional Variation of Maya Spiked Vessels: A Practical Guide. American Antiquity 47:614-633.

Deletaille, Lin, Emile Deletaille, and H. Van Geluwe

1992 Schatten uit de Nieuwe Wereld: Musees royaux d'art et d'histoire (Belgium). Koninklijke Musea voor Kunst en Geschiedenis, Brussels.

Drucker, Philip

1947 Survey (of) Gulf of Tehuantepec Coast, N.G.S. Smithsonian Institution Expedition, February to June, 1947. Field notebook. The objects. Voorhies is particularly grateful to Ron Bishop and Erin Sears for twice extending warm hospitality when she revisited the material. Finally, we thank Rob Rosenswig and two anonymous reviewers for helpful suggestions that have allowed us to strengthen our article and to Elizabeth Graham for providing information about an effigy vessel from Lamanai.

National Anthropological Archives, Smithsonian Institution, Washington, DC.

1948 Preliminary Notes on an Archaeological Survey of the Chiapas Coast. Middle American Research Records 1:151-169.

Díaz, Gisele, and Alan Rodgers

1993 The Codex Borgia: A Full-Color Restoration of the Ancient Mexican Manuscript. Dover Publications, New York.

Ekholm, Susanna M.

1979 The Lagartero Figurines. In Maya Archaeology and Ethnohistory, edited by Norman Hammond and Gordon R. Willey, pp. 172-186. University of Texas Press, Austin.

Elson, Christina M., and Michael E. Smith

2001 Archaeological Deposits from the Aztec New Fire Ceremony. Ancient Mesoamerica 12:157-174.

Freidel, David, Linda Schele, and Joy Parker

1993 Maya Cosmos: Three Thousand Years on the Shaman's Path. William Morrow, New York.

García-Des Lauriers, Claudia

2005 La iconografía y simbolismo de la escultura de Cerro Bernal, Chiapas. In Iconografía y escritura Teotihuacana en la costa sur de Guatemala y Chiapas, edited by Oswaldo Chinchilla Mazariegos and Bárbara Arroyo, pp. 1-16. Utz'ib, Serie Reportes, Vol. 1, No. 5. Tikal Association, Guatemala City.

2007 Proyecto Arqueológico Los Horcones: Investigating the Teotihuacan Presence on the Pacific Coast of Chiapas, Mexico. Unpublished Ph.D. dissertation, Department of Anthropology, University of California, Riverside.

Goldstein, Marilyn

1977 The Ceremonial Role of the Maya Flanged Censer. Man 12: 405-420.

Graham, Elizabeth

2011 Maya Christians and their Churches in Sixteenth-Century Belize. University Press of Florida, Gainesville.

Guernsey, Julia

2006 Ritual and Power in Stone: The Performance of Rulership in Mesoamerican Izapan Style Art. University of Texas Press, Austin.

Heyden, Doris

1987 Symbolism of Ceramics from the Templo Mayor. In The Aztec Templo Mayor, edited by Elizabeth Hill Boone, pp. 109-130. Dumbarton Oaks Research Library and Collection, Washington, DC.

Kidder, Alfred V.

1950 Certain Archaeological Specimens from Guatemala, Part II. Notes on Middle American Archaeology and Ethnology, No. 95. Carnegie Institution of Washington, Washington, DC.

Klein, Cecelia

1980 Who was Tlaloc? Journal of Latin American Lore 6:155-204.

Langley, James

1997 Teotihuacan Incensarios: The ' $\mathrm{V}$ ' Manta and its Message. Teotihuacan Notes: Internet Journal for Teotihuacan Archaeology and Iconography I-3:1-11. Electronic document, http://archaeology. asu.edu/TeO/notes/JL/notes1_3.htm, accessed December 3, 2010.

López Luján, Leonardo

2006 La casa de las águilas: Un ejemplo de la arquitectura religiosa de Tenochtitlan. 2 vols. Fondo de Cultura Económica, Mexico City.

Lowe, Gareth W.

1965 Desarrollo y función del incensario en Izapa. Estudios de Cultura Maya 5:53-64.

Matos Moctezuma, Eduardo

1987 Symbolism of the Templo Mayor. In The Aztec Templo Mayor, edited by Elizabeth Hill Boone, pp. 185-209. Dumbarton Oaks Research Library and Collection, Washington, DC.

Maudslay, Alfred P.

1889-1902 Archaeology: Biologia Centrali-Americana, Vols. 1 and 2. Porter and Dulau, London. 
Norman, Garth V.

1973 Izapa Sculpture: Part 1: Album. Papers of the New World Archaeological Foundation, No. 30. Brigham Young University, Provo.

1976 Izapa Sculpture: Part 2: Text. Papers of the New World Archaeological Foundation, No. 30. Brigham Young University, Provo.

Nuttall, Zelia

1975 The Codex Nuttall: A Picture Manuscript from Ancient Mexico. Dover Publications, New York.

Pasztory, Esther

1974 The Iconography of the Teotihucan Tlaloc. Dumbarton Oaks Studies in Pre-Columbian Art and Archaeology, No. 15. Dumbarton Oaks Research Library and Collection, Washington, DC.

Pendergast, David M.

2006 Patterns of Cache Composition and Placement at Lamanai, Belize. In Reconstructing the Past: Studies in Mesoamerican and Central American Prehistory, edited by David M. Pendergast and Anthony P. Andrews, pp. 59-69. BAR International Series 1529. British Archaeological Reports, Oxford.

Pennington, T. D., and J. Sarukhán

1998 Arboles tropicales de México: Manual para la identificación de las principales especies. Universidad Nacional Autónoma de Mexico, Fondo de Cultura Económica, Mexico City.

Pohl, John M. D., and Claire L. Lyons

2010 The Aztec Pantheon and the Art of Empire. The J. Paul Getty Museum, Los Angeles.

Rice, Prudence M.

1999 Rethinking Classic Lowland Maya Pottery Censers. Ancient Mesoamerica 10:25-50.

Rosenswig, Robert M.

2009 Early Mesoamerican Garbage: Ceramic and Daub Discard Patterns from Cuauhtémoc, Soconusco, Mexico. Journal of Archaeological Method and Theory 16:1-32.

Sahagún, Bernardino de

1953 Florentine Codex: General History of the Things of New Spain. Book 7: The Sun, Moon, Stars, and the Binding of the Years. Translated by Arthur J. O. Anderson and Charles E. Dibble. The School of American Research, Santa Fe, and the University of Utah, Salt Lake City.

1981 Florentine Codex: General History of the Things of New Spain. Book 2: The Ceremonies. Translated by Arthur J. O. Anderson and Charles E. Dibble. The School of American Research, Santa Fe, and the University of Utah, Salt Lake City.

Schmidt, Peter, Mercedes de la Garza, and Enrique Nalda

1998 Maya. Exhibition Catalogue. Rizzoli, New York.

Schiffer, Michael B.

1983 Toward the Identification of Formation Processes. American Antiquity 48:675-706.

1987 Formation Processes of the Archaeological Record. The University of New Mexico Press, Albuquerque.
Seler, Eduard

1963 Comentarios al Códice Borgia. Facsimile edition. 3 vols. Commentaries translated by Mariana Frenk. Fondo de Cultura Económica, Mexico City.

Stark, Barbara L., and Michael Ohnersorgen

2001 Comparative Analysis of the Deposits: Concepts and Analysis. In Classic Period Mixtequilla, Veracruz, Mexico: Diachronic Inferences from Residential Investigations, edited by Barbara L. Stark, pp. 253-261. Institute for Mesoamerican Studies, Monograph 12. State University of New York, Albany, Albany.

Taube, Karl A.

1998 The Jade Hearth: Centrality, Rulership and the Classic Maya Temple. In Function and Meaning in Classic Maya Architecture, edited by Stephen D. Houston, pp. 427-458. Dumbarton Oaks Research Library and Collection, Washington, DC.

Thompson, J. Eric S.

1970 Maya History and Religion. University of Oklahoma Press, Norman.

Townsend, Richard

1987 Coronation at Tenochtitlan. In The Aztec Templo Mayor, edited by Elizabeth Hill Boone, pp. 371-410. Dumbarton Oaks Research Library and Collection, Washington, DC.

Tozzer, Alfred M

1907 A Comparative Study of the Mayas and Lacandones. Archaeological Institute of America Report of the Fellow in American Archaeology: 1902-1905. Macmillan, London.

1966 [1941] Landa's Relación de las cosas de Yucatan: a translation. Papers of the Peabody Museum of American Archaeology and Ethnology, Vol. 18. Harvard University, Klaus Reprint Corporation, Cambridge, MA.

Urcid, Javier

2005 Zapotec Writing: Knowledge, Power, and Memory in Ancient Oaxaca. Electronic document, http://www.famsi.org/zapotecwriting/, accessed March 29, 2016.

Voorhies, Barbara

1989 Settlement Patterns in the Western Soconusco: Methods of Site Recovery and Dating Results. In New Frontiers in the Archaeology of the Pacific Coast of Mesoamerica, edited by Frederick J. Bové and Lynette Heller, pp. 1-22. Arizona Research Papers, No. 39. Arizona State University, Tempe.

Voorhies, Barbara and Janine Gasco

2004 Postclassic Soconusco Society: The Late Prehistory of the Coast of Chiapas, Mexico. Institute for Mesoamerican Studies Monograph 14. University at Albany, Albany.

Voorhies, Barbara, Janine Gasco, and Paul Cackler

2011 Prehistoric Settlement in the South Pacific Coast of Chiapas, Mexico. Papers of the New World Archaeological Foundation, No. 71. Brigham Young University, Provo.

Wauchope, Robert

1975 Zacualpa, El Quiche, Guatemala: An Ancient Provincial Center of the Highland Maya. Middle American Research Institute, Publication No. 39. Tulane University, New Orleans. 